\title{
Inductively Coupled Plasma (ICP)
}

\author{
Ali Al-Dousari, Fatin Al-Mutawaa, Hanan Al-Mansour, \\ and Badreya Mandekar
}

\section{Abstract}

- The crushed powder from defined dust particle size fractions was analyzed using inductively coupled spectrometry plasma (ICP) for major and trace elements.

- The ICP was used for the determination of concentrations of trace elements and six major elements: (Al, Fe, Mg, $\mathrm{Ca}, \mathrm{Na}$, and $\mathrm{K}$ ) and five minor elements ( $\mathrm{Ba}, \mathrm{Cr}, \mathrm{V}, \mathrm{Ti}$, and $\mathrm{Pb}$ ). They are quoted in part per million (ppm).

- Maps showing high and low concentrations of ICP among Kuwait.

\section{ICP (Inductively Coupled Plasma) Spectrometry Analysis}

The crushed powder from defined dust particle size fractions was analyzed using ICP to identify major and trace elements. The reason for using ICP to analyze major elements was

A. Al-Dousari $(\bowtie)$

Crisis Decision Supports Program (CDS), Environment and Life

Sciences Research Center (ELSRC), Kuwait Institute for Scientific Research (KISR), P.O. Box 24885 Safat, 13109, Kuwait

e-mail: adousari@kisr.edu.kw

\section{F. Al-Mutawaa}

Nanotechnology and Advanced Materials Program (NAM), Energy and Building Research Center (EBRC), Kuwait Institute for Scientific Research (KISR), P.O. Box 24885 Safat, 13109,

Kuwait

e-mail: fmutawa@kisr.edu.kw

\section{H. Al-Mansour}

Environmental Pollution and Climate Program (EPCP), Environment and Life Sciences Research Center (ELSRC),

Kuwait Institute for Scientific Research (KISR), P.O. Box 24885

Safat, 13109, Kuwait

e-mail: hsultan@kisr.edu.kw

\section{B. Mandekar}

Analytical Chemistry Division, General Department of Criminal

Evidence, Criminal Secure, Ministry of Interior, P.O. Box 11

Safat, 13001, Kuwait

e-mail: bedraya.mandekar@moi.gov.kw because some samples had less weight than needed $(7 \mathrm{~g})$ for analysis by XRF, while only $2 \mathrm{~g}( \pm 0.05)$ of powder is used in the ICP method. The method used for dissolved sediment samples for ICP involved open evaporation of the sample with hydrofluoric acid, together with nitric acid $\left(\mathrm{HNO}_{3}\right)$, in a platinum crucible.

The ICP was used to determine the concentrations of trace elements and six major elements: (Al, $\mathrm{Fe}, \mathrm{Mg}, \mathrm{Ca}, \mathrm{Na}$, and $\mathrm{K}$ ) and five minor elements ( $\mathrm{Ba}, \mathrm{Cr}, \mathrm{V}, \mathrm{Ti}$, and $\mathrm{Pb})$. The amounts are quoted in parts per million (ppm) (Fig. 5.1).

\section{Iron (Fe)}

Iron (Fe) plays a major role in the biochemical reactions within a marine environment and acts as a major feeder to microorganisms (e.g., phytoplankton, cyanobacteria). The average amount of iron within fallen dust varies from 13,000 to $57,000 \mathrm{ppm}$. The distribution of areas with higher concentrations of iron indicates the effect of northeastern wind coming from the Zagros Mountains. The southern coastal areas had the highest concentrations of iron. There were some areas with high iron concentrations in a straight line from Bubiyan Island in the northeast toward Atraf in the southeast. The lowest concentration of iron in Kuwait was recorded in March and September, while the highest was in December (Figs. 5.1 and 5.2).

\begin{tabular}{l|l}
\hline $\begin{array}{l}\text { Areas with high ICP } \\
\text { concentration }\end{array}$ & $\begin{array}{l}\text { Areas with low ICP } \\
\text { concentration }\end{array}$ \\
\hline Um Eish & Um Niqa \\
Salmiya & Ratqah \\
Shuaiba & Dibdibah \\
Khiran & Sulaybiyah \\
Parts of Bubiyan Island & Wafra farms \\
\hline
\end{tabular}




\section{Aluminum (Al)}

Aluminum as an element is a major indication of higher concentrations of alkali and plagioclase feldspar minerals. The average amount of aluminum within fallen dust varies from $3000 \mathrm{ppm}$ to more than $80,000 \mathrm{ppm}$ (average: $41,246 \mathrm{ppm}$ ). The distribution of areas with higher concentrations of aluminum is sporadic and without trend. September was an exceptional case; the Western Desert areas had lower concentrations than the coastal areas. The lowest concentration in Kuwait was in September, while the highest was in December (Figs. 5.3 and 5.4).

\begin{tabular}{l|l}
\hline $\begin{array}{l}\text { Areas with high ICP } \\
\text { concentration }\end{array}$ & $\begin{array}{l}\text { Areas with low ICP } \\
\text { concentration }\end{array}$ \\
\hline Salmi & Subiyah \\
Abdulli & Abdulli \\
Um Niqa & Roudhatain \\
Um Rimam & Kabd \\
Shuaiba & Wafra farms \\
\hline
\end{tabular}

\section{Barium (Ba)}

Barium ( $\mathrm{Ba}$ ) as an element is a major indication of higher concentrations of alkali and plagioclase feldspar minerals. The average amount of aluminum within fallen dust varies from $3000 \mathrm{ppm}$ to more than $80,000 \mathrm{ppm}$ (average: $41,246 \mathrm{ppm})$. The distribution of areas with higher concentrations of Ba was found mainly in three locations: Abdulli, Shuaiba, and northern Kuwait Bay in Sabah Al-Ahmed National Reserve. The lowest concentration in Kuwait was recorded in June, while the highest was in March and September (Figs. 5.5 and 5.6).

\begin{tabular}{l|l}
\hline $\begin{array}{l}\text { Areas with high ICP } \\
\text { concentration }\end{array}$ & $\begin{array}{l}\text { Areas with low ICP } \\
\text { concentration }\end{array}$ \\
\hline Abdulli & Bubiyan Island \\
Um Eish & Ubayriq \\
Salmiya & Dibdibah \\
Shuaiba & Khur Fawaris \\
Burqan & Khiran \\
\hline
\end{tabular}

\section{Calcium (Ca)}

Calcium $(\mathrm{Ca})$ as an element is a major indication of higher concentrations of plagioclase feldspars and heavy minerals. The average amount of calcium within fallen dust varies from $1247 \mathrm{ppm}$ to more than $115,500 \mathrm{ppm}$ (average: $48,318 \mathrm{ppm}$ ). The higher distribution areas cover most of Kuwait, but, on average, the northern areas had higher concentrations than southern Kuwait. The lowest concentration in Kuwait was in June, while the highest was in December (Figs. 5.7 and 5.8).

\begin{tabular}{l|l}
\hline $\begin{array}{l}\text { Areas with high ICP } \\
\text { concentration }\end{array}$ & $\begin{array}{l}\text { Areas with low ICP } \\
\text { concentration }\end{array}$ \\
\hline Salmi & Jal Al Zur \\
Ratqah & Ubayriq \\
Bubiyan Island & Kabd \\
Khiran & Ahmadi \\
Um Eish & Wafra farms \\
\hline
\end{tabular}

Fig. 5.1 Average iron (Fe) content in ppm within fallen dust in Kuwait (2010)

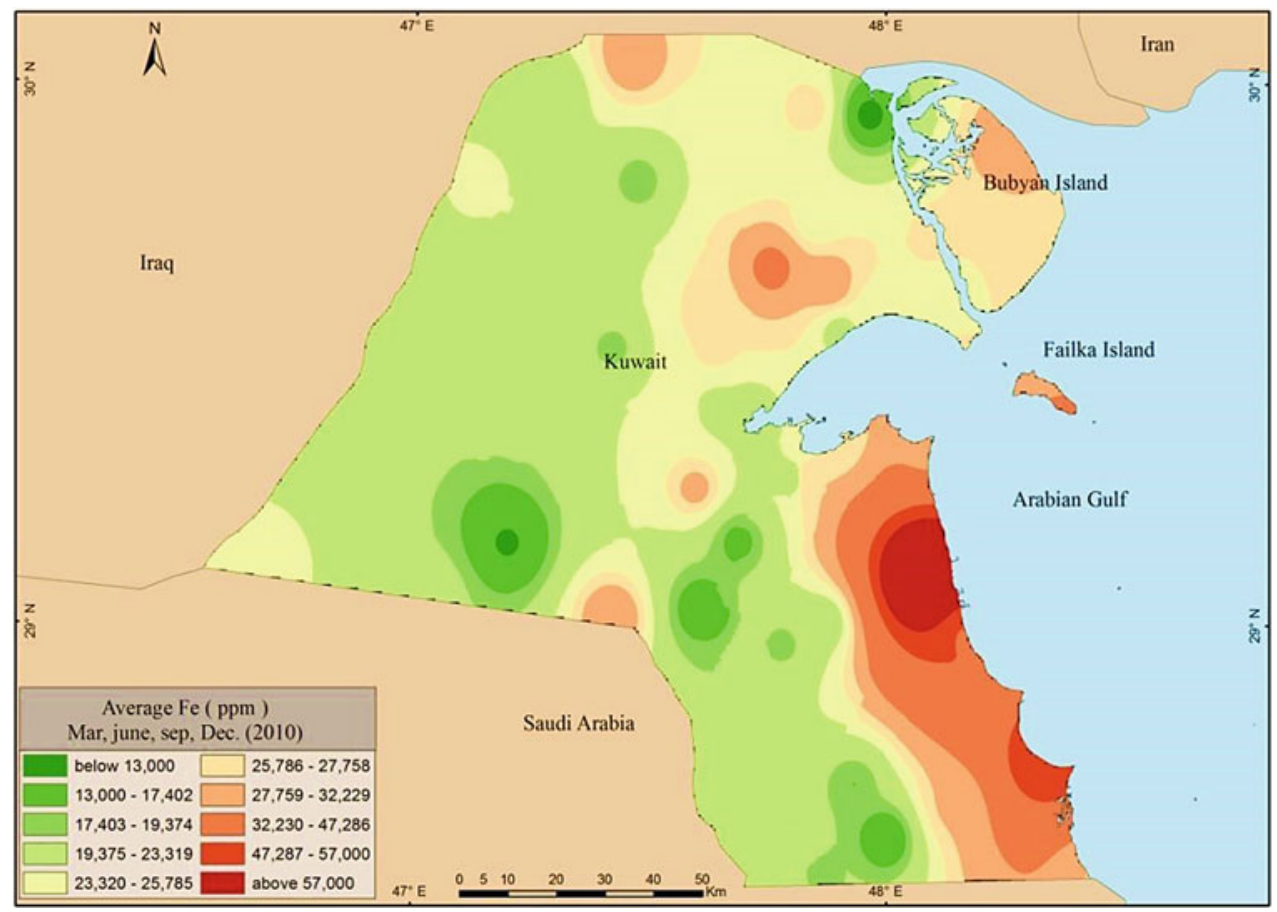



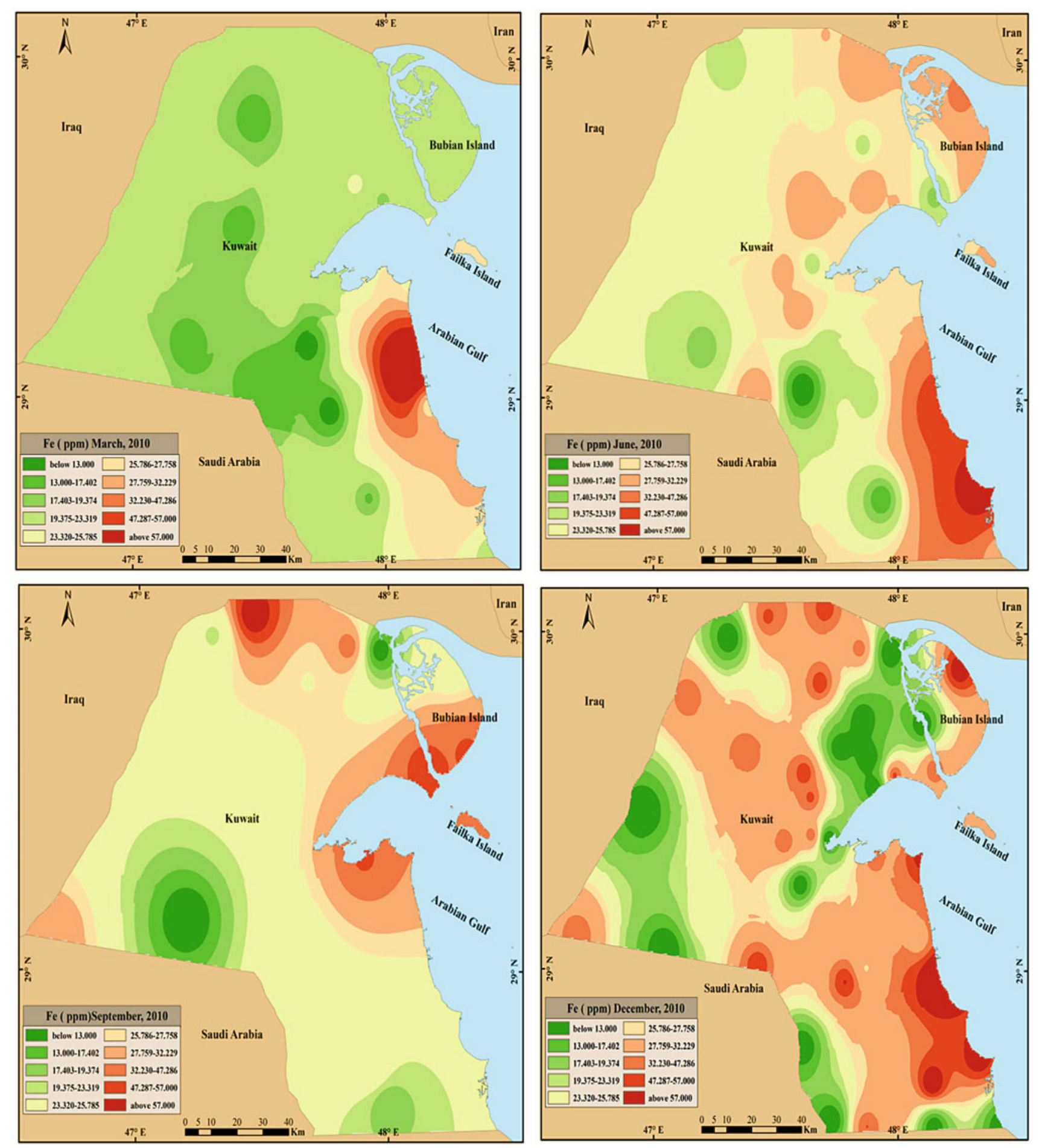

Fig. 5.2 Fe content in ppm within fallen dust in Kuwait (2010)

\section{Chromium (Cr)}

Chromium with iron plays a major role in the biochemical reactions within marine environments and acts as a major feeder to microorganisms (e.g., phytoplankton, cyanobacteria). The average amount of chromium within fallen dust varies from 28 to $2128 \mathrm{ppm}$. The chromium higher distribution areas are similar to that of iron. Bubiyan Island and areas around Kuwait Bay were the highest areas of chromium. The lowest concentration in Kuwait was in December, while the highest was in September (Figs. 5.9 and 5.10). 
Fig. 5.3 Average aluminum (Al) content in ppm within fallen dust in Kuwait (2010)

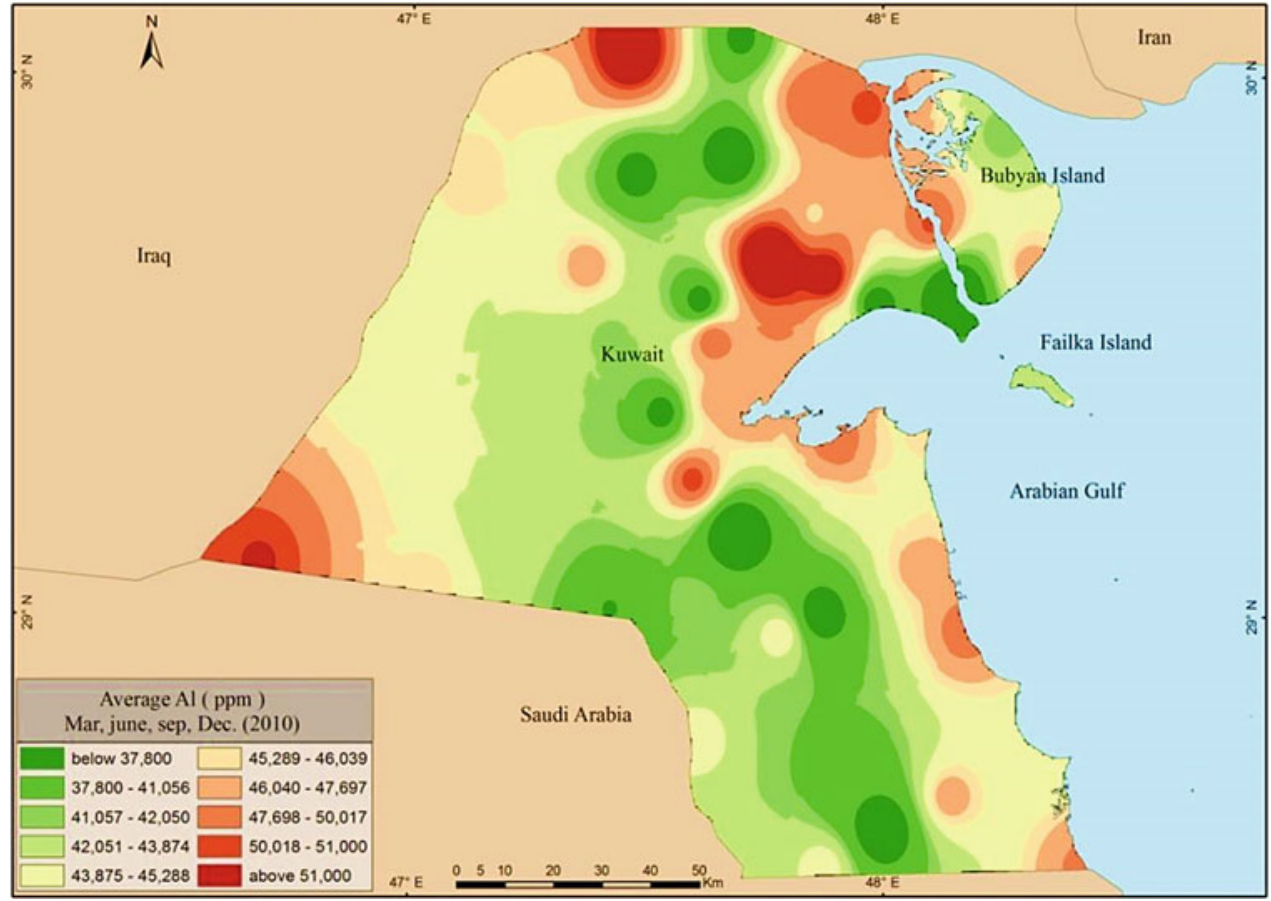

Areas with low ICP concentration

\begin{tabular}{l|l}
$\begin{array}{l}\text { Areas with high ICP } \\
\text { concentration }\end{array}$ & $\begin{array}{l}\text { Areas with low ICP } \\
\text { concentration }\end{array}$ \\
\hline Bubiyan Island & Salmi \\
Abdulli & Liyah \\
Jal Al Zur & Burqan \\
Salmiya & Qurain \\
Atraf & Wafra farms \\
\hline
\end{tabular}

\section{Potassium (K)}

Potassium (K) as an element is a major indication of higher concentrations of alkali feldspar minerals. The average amount of potassium within fallen dust varies from $848 \mathrm{ppm}$ to more than $178,600 \mathrm{ppm}$ (average: $18,035 \mathrm{ppm}$ ). The higher distribution areas of potassium are associated with major wind corridors in western (Salmi) and northeastern areas (Bubiyan and Subiyah) in Kuwait. The lowest concentration in Kuwait was in June, while the highest was in September and December (Figs. 5.11 and 5.12).

\begin{tabular}{l|l}
\hline $\begin{array}{l}\text { Areas with high ICP } \\
\text { concentration }\end{array}$ & $\begin{array}{l}\text { Areas with low ICP } \\
\text { concentration }\end{array}$ \\
\hline $\begin{array}{l}\text { Parts of Bubiyan Island } \\
\text { Um Eish }\end{array}$ & $\begin{array}{l}\text { Shuaiba } \\
\text { Wafra farms }\end{array}$ \\
Salmi & Sulaybiyah \\
Kabd & Ratqah \\
Khur Fawaris & Liyah
\end{tabular}

\section{Magnesium (Mg)}

The presence of magnesium $(\mathrm{Mg})$ as an element indicates higher concentrations of heavy minerals. The average amount of magnesium within fallen dust varies from $1247 \mathrm{ppm}$ to more than $115,500 \mathrm{ppm}$ (average: 48,318 ppm). Magnesium's higher distribution areas are in the northern and northeastern sides of Kuwait more than in the south and far west. The lowest concentration in Kuwait was in September, while the highest was recorded in March (springtime with low wind activity) (Figs. 5.13 and 5.14).

\begin{tabular}{l|l}
\hline $\begin{array}{l}\text { Areas with high ICP } \\
\text { concentration }\end{array}$ & $\begin{array}{l}\text { Areas with low ICP } \\
\text { concentration }\end{array}$ \\
\hline Abdulli & Salmi \\
Subiyah & Ubayriq \\
Um Eish & Sulaybiyah \\
Atraf & Burqan \\
Kabd & Wafra farms \\
\hline
\end{tabular}

\section{Sodium (Na)}

The presence of sodium $(\mathrm{Na})$ as an element indicates higher concentrations of alkali feldspar minerals and salt content within dust samples. The average amount of sodium within the fallen dust varies from $941 \mathrm{ppm}$ to more than 62,700 ppm (average: $9091 \mathrm{ppm}$ ). The sodium higher 

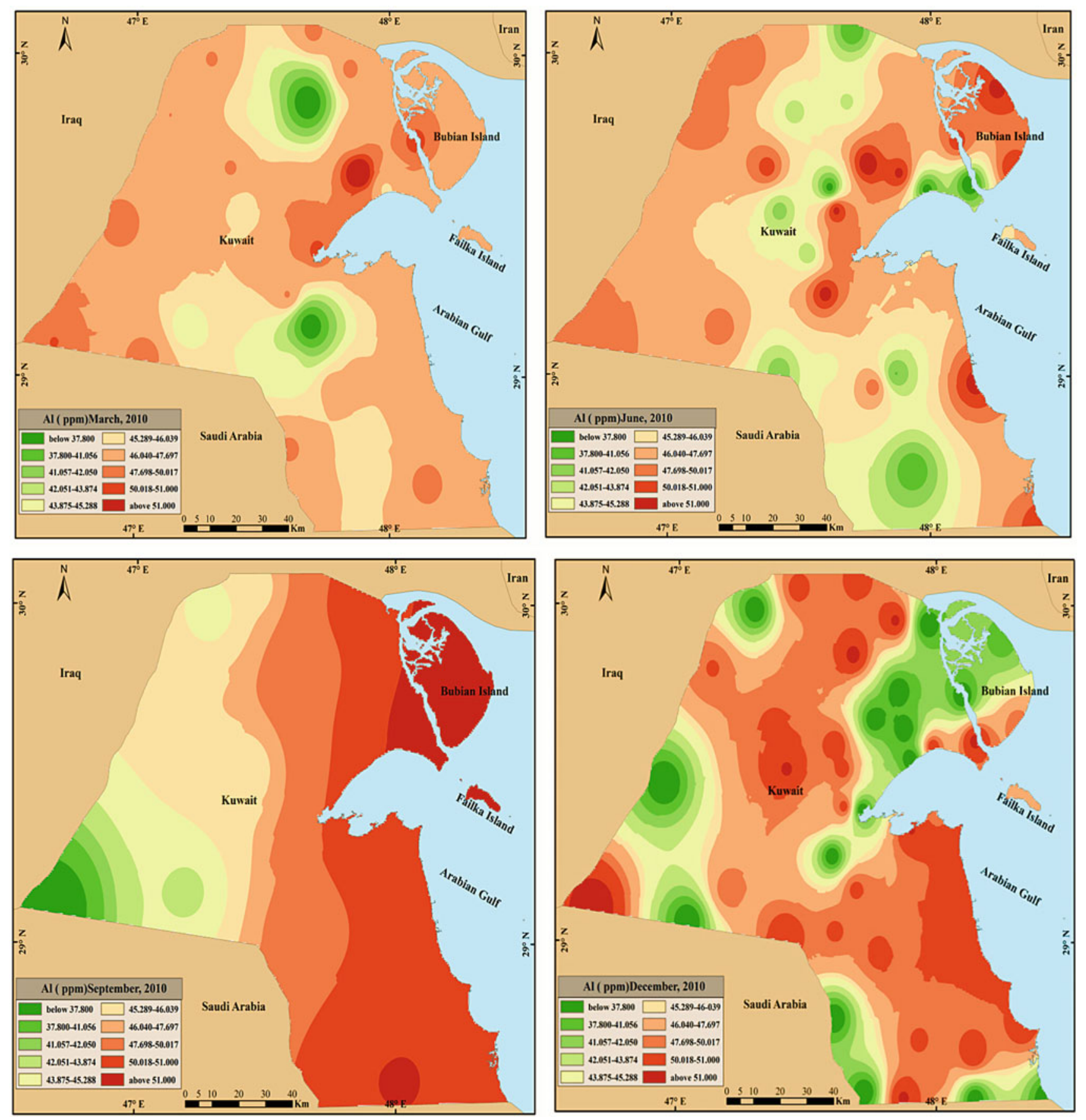

Fig. 5.4 Al content in ppm within fallen dust in Kuwait (2010)

distribution areas are associated with major wind corridors in northwestern areas (Um Al Madafi), with low concentrations in farms and preserved areas with dense vegetation. The lowest concentration in Kuwait was in March, while the highest was in June (Figs. 5.15 and 5.16).
Areas with high ICP concentration

Bubiyan Island

Ratqah

Um Al Madafi'

Liyah

Salmiya
Areas with low ICP concentration

Salmi

Abdulli

Urayfijan

Khur Fawaris

Wafra farms 
Fig. 5.5 Average barium

(Ba) content in ppm within fallen dust in Kuwait (2010)

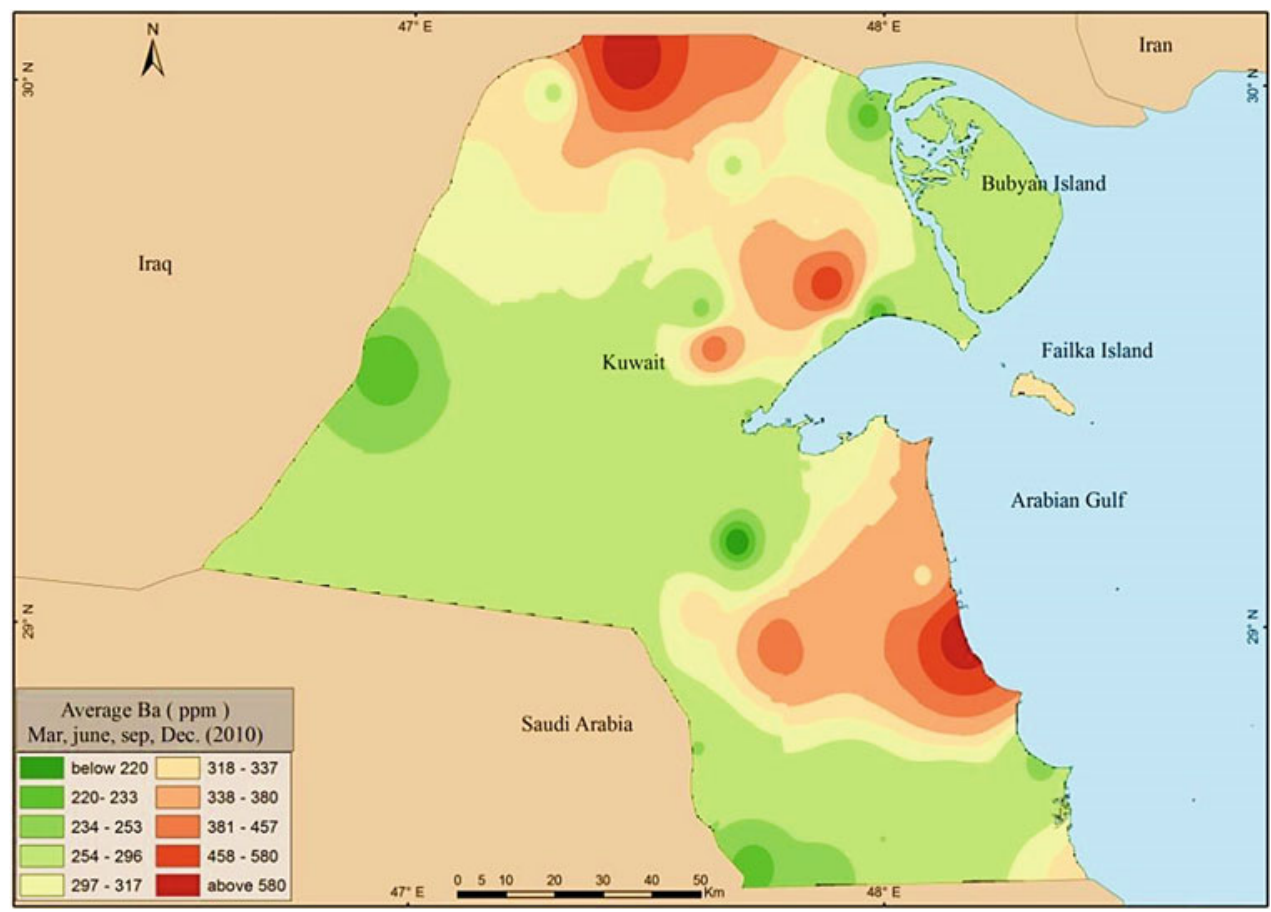

\section{Lead $(\mathrm{Pb})$}

The presence of lead $(\mathrm{Pb})$ and magnesium $(\mathrm{Mg})$ as elements indicates higher concentrations of heavy minerals within the dust. The average amount of lead within fallen dust varies from $6 \mathrm{ppm}$ to more than $8500 \mathrm{ppm}$ (average: $2168 \mathrm{ppm}$ ). Lead's higher distribution areas cover the northeastern sides of Kuwait more than the south and far west, which might offer some indications regarding the source areas, especially the Mesopotamian Floodplain and the Zagros Mountains. The lowest concentrations in Kuwait were in December and September, while the highest was in March. Furthermore, there is another trend: a high lead concentration that extends from Um Al Madafi toward Atraf in Kuwait (Figs. 5.17 and 5.18).

\begin{tabular}{l|l}
\hline $\begin{array}{l}\text { Areas with high ICP } \\
\text { concentration }\end{array}$ & $\begin{array}{l}\text { Areas with low ICP } \\
\text { concentration }\end{array}$ \\
\hline $\begin{array}{l}\text { Bubiyan Island } \\
\text { Subiyah }\end{array}$ & Ratqah \\
Abdulli & Ubayriq \\
Um Al Madafi & Dibdibah \\
Atraf & Burqan \\
& Wafra farms
\end{tabular}

\section{Titanium (Ti)}

The average amount of titanium within the fallen dust varies from $4 \mathrm{ppm}$ to $8873 \mathrm{ppm}$ (average: $2328 \mathrm{ppm}$ ). The presence of titanium as an element indicates higher concentrations of heavy minerals within dust. The titanium distribution was higher in areas around Kuwait Bay, western areas, and the southern coastal zone of Kuwait, indicating higher concentrations than in the northern and central areas of Kuwait. The lowest concentration in Kuwait was in summer, during September and June, while the highest was in December and March (Figs. 5.19 and 5.20).

\begin{tabular}{l|l}
\hline $\begin{array}{l}\text { Areas with high ICP } \\
\text { concentration }\end{array}$ & $\begin{array}{l}\text { Areas with low ICP } \\
\text { concentration }\end{array}$ \\
\hline Subiyah & Bubiyan Island \\
Um Rimam & Abdulli \\
Salmiya & Um Eish \\
Shuaiba & Burqan \\
Ubayriq & Wafra farms \\
\hline
\end{tabular}



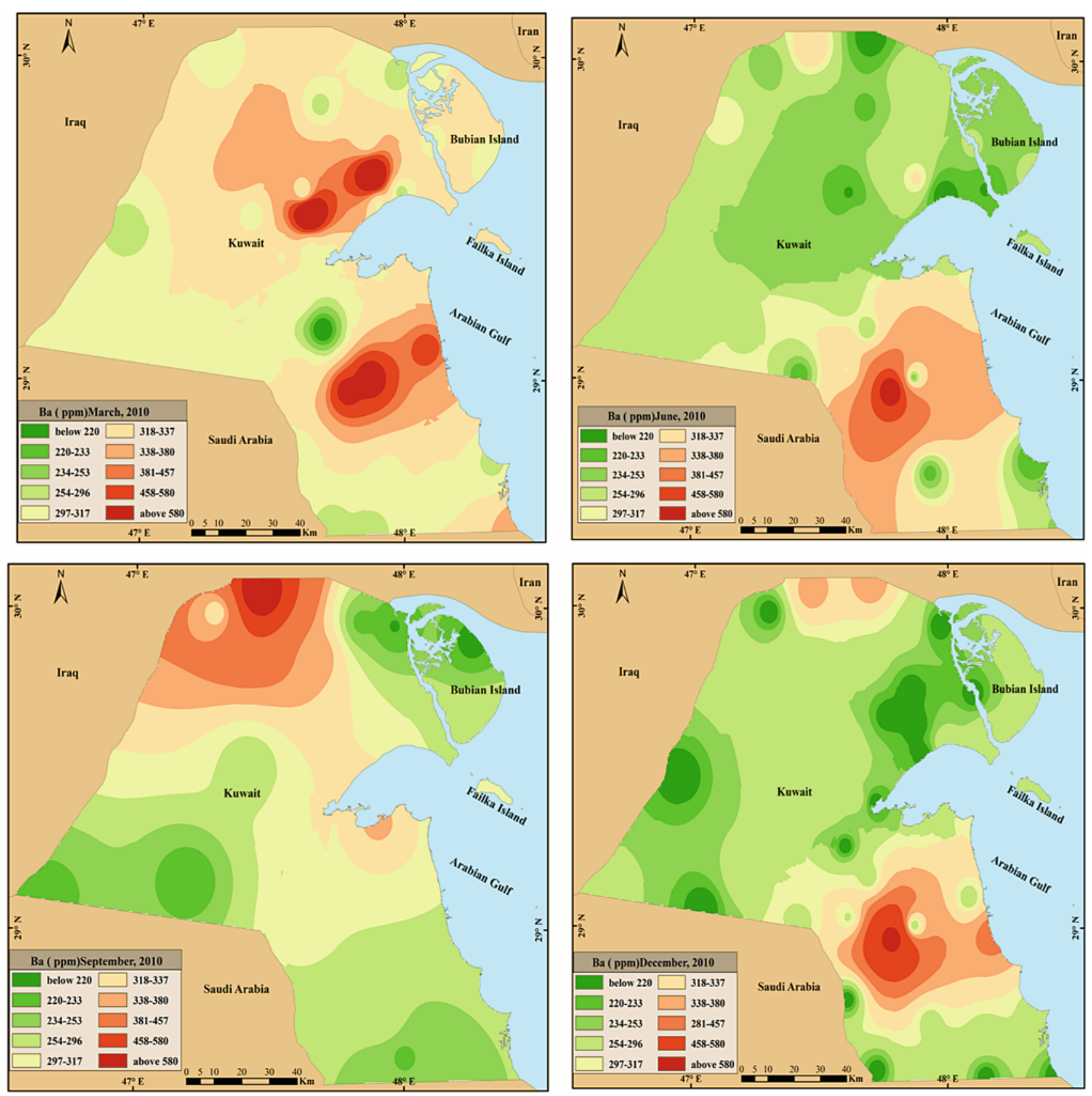

Fig. 5.6 Ba content in ppm within fallen dust in Kuwait (2010)

\section{Vanadium (V)}

The average amount of vanadium $(\mathrm{V})$ within fallen dust varies from 11 to $153 \mathrm{ppm}$ (average: $2328 \mathrm{ppm}$ ), which is the lowest concentration (in addition to thallium [TL]) of all the detected elements within dust fallout. The presence of vanadium as an element indicates higher concentrations of heavy minerals within dust. The highest distribution of vanadium was present around the coastal zone and northeastern areas of Kuwait. The lowest concentration in Kuwait was in December, while the highest was in March (Figs. 5.21 and 5.22).

Areas with high dust fallout concentration

Areas with low ICP

Bubiyan Island

Subiyah

Abdulli

Salmiya

Um Rimam concentration

Ratqah

Ubayriq

Dibdibah

Burqan

Wafra farms 


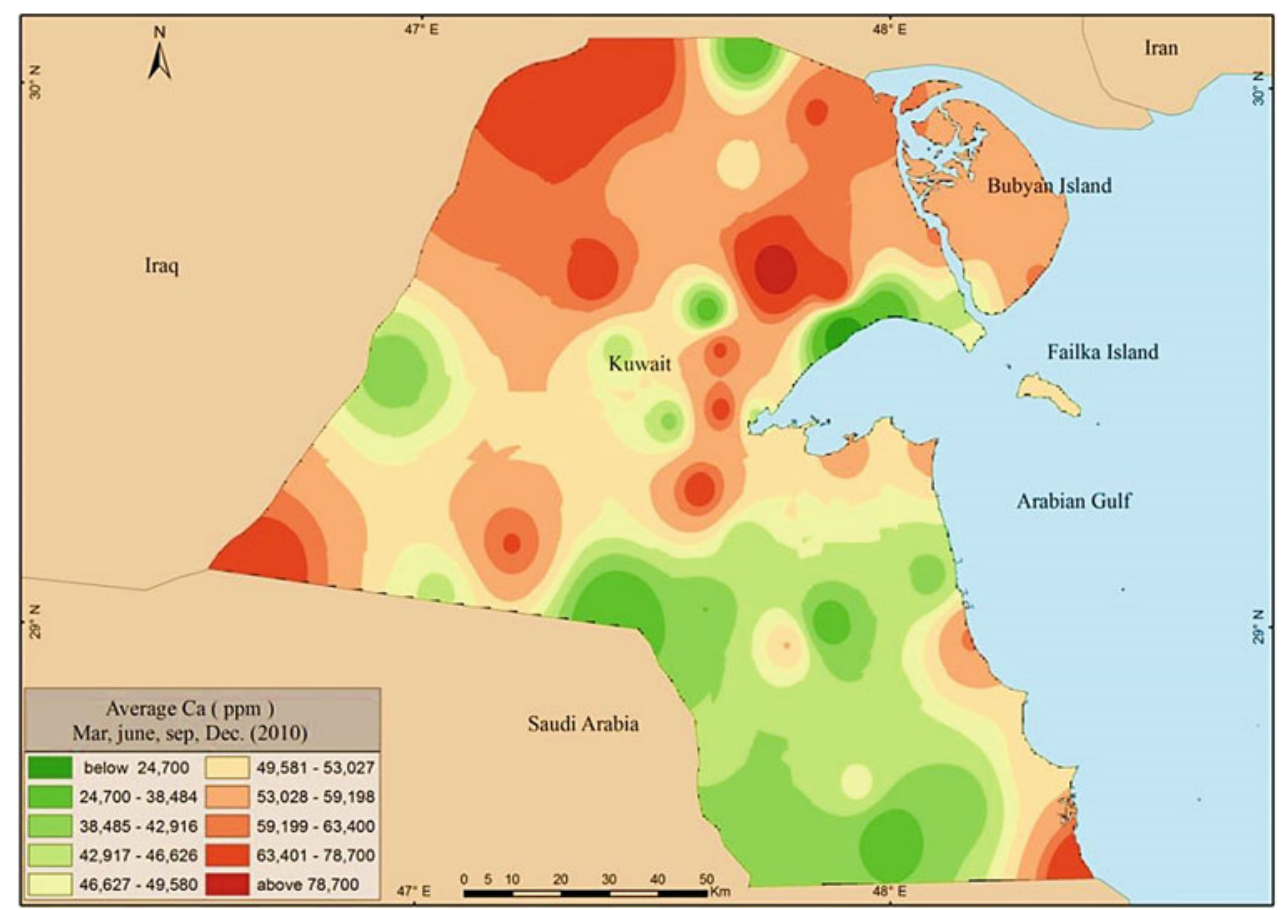

Fig. 5.7 Average calcium (Ca) content in ppm within fallen dust in Kuwait (2010)
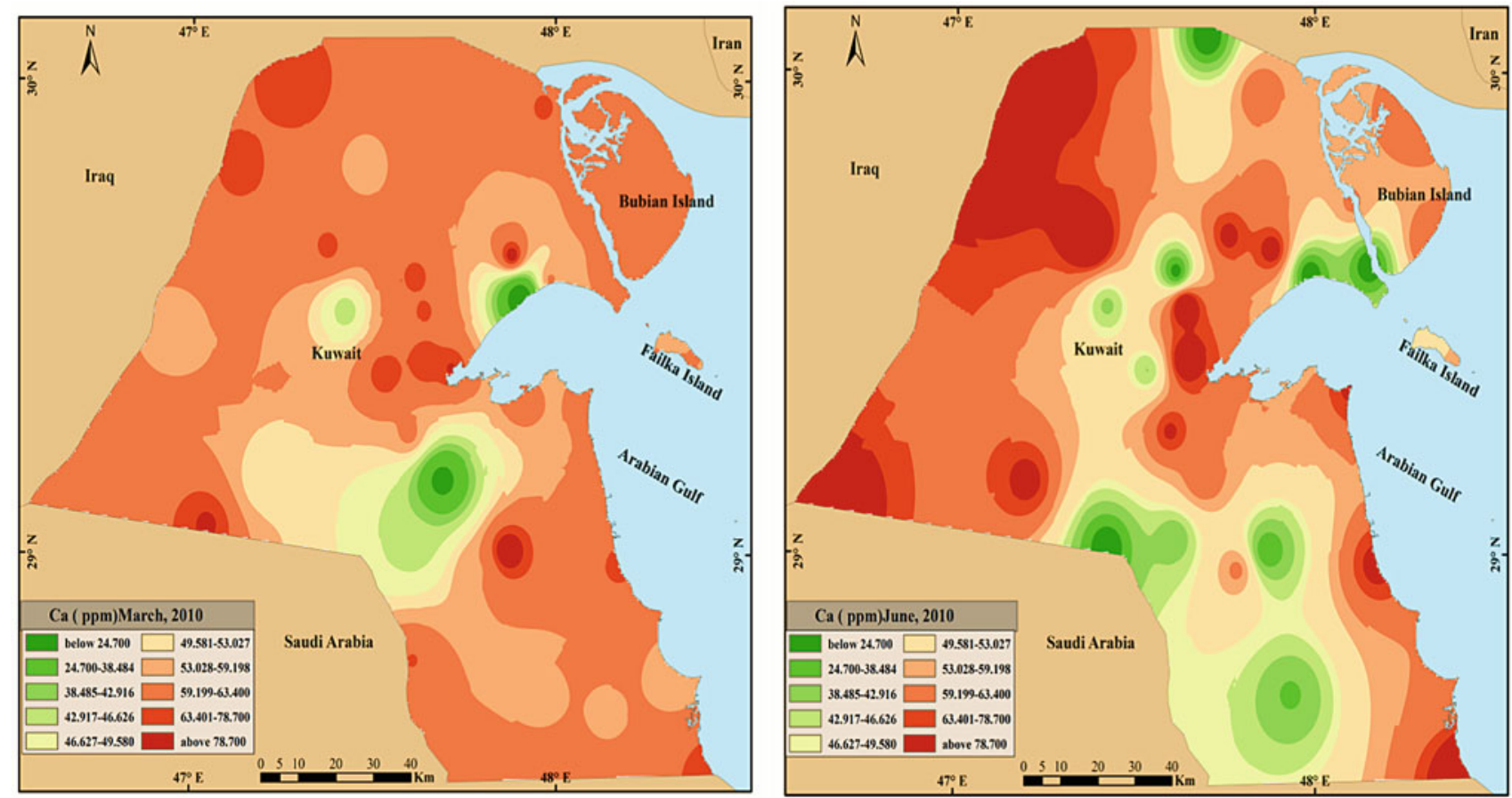

Fig. 5.8 Ca content in ppm within fallen dust in Kuwait (2010) 

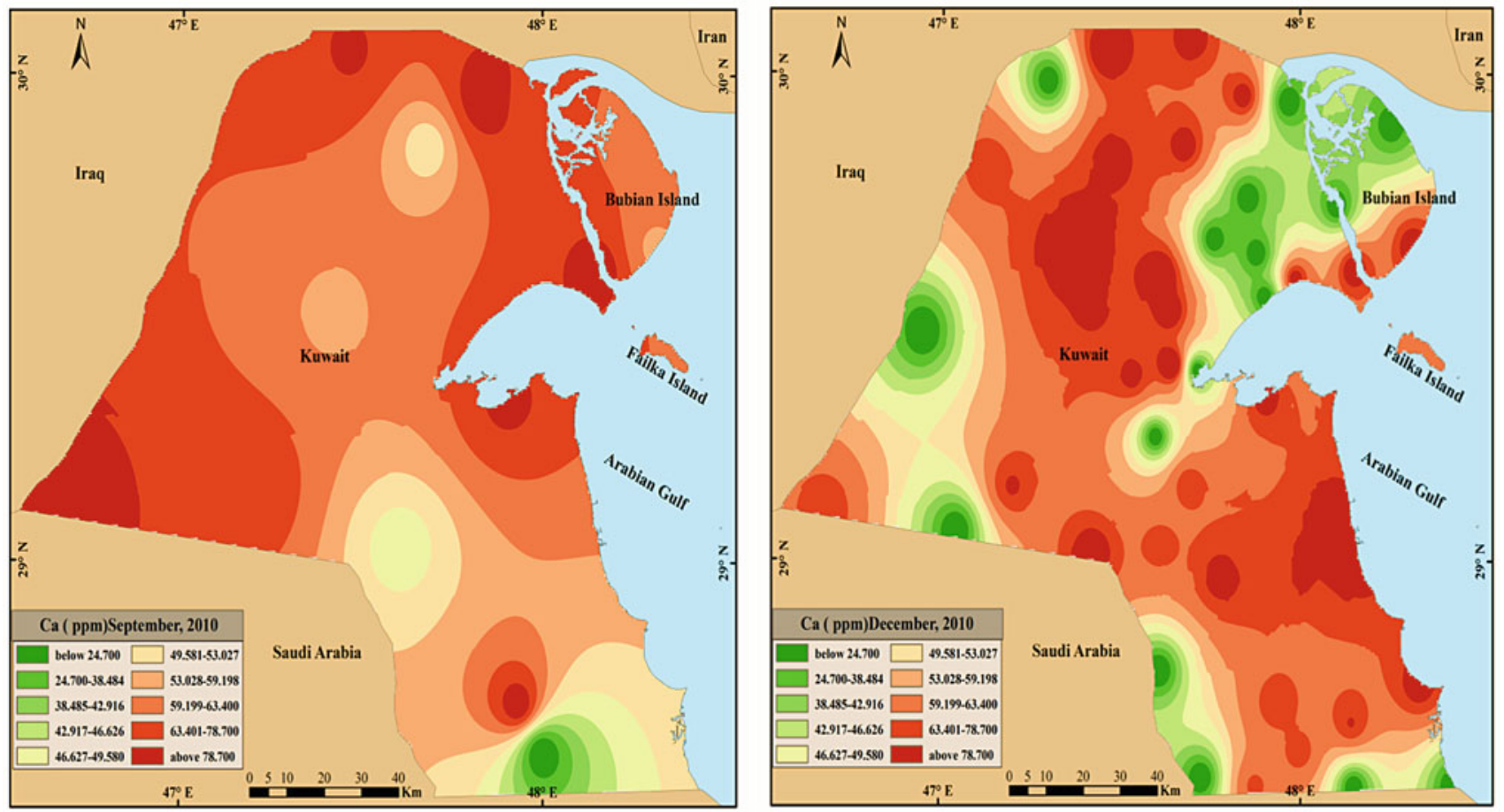

Fig. 5.8 (continued)

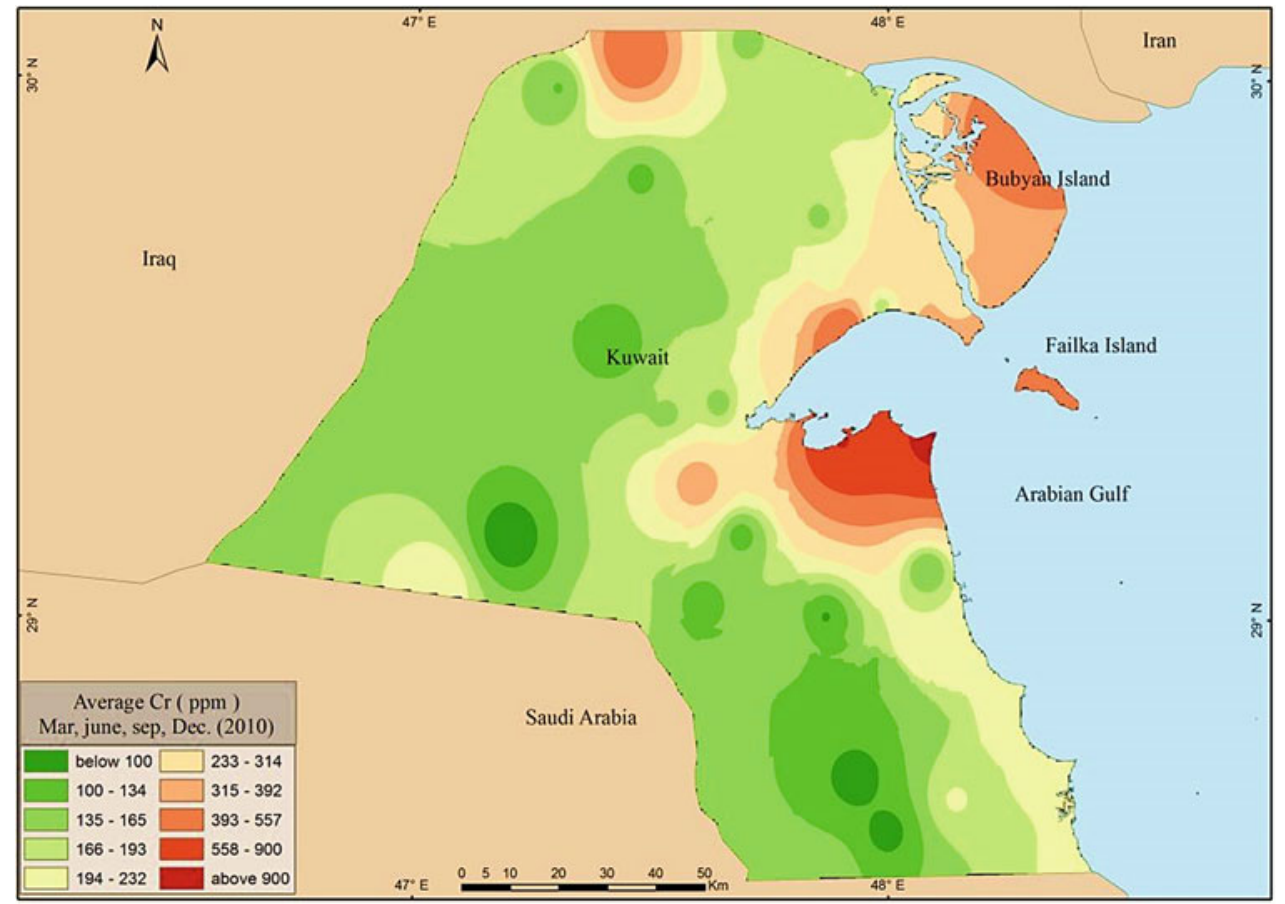

Fig. 5.9 Average chromium (Cr) content in ppm within fallen dust in Kuwait (2010) 

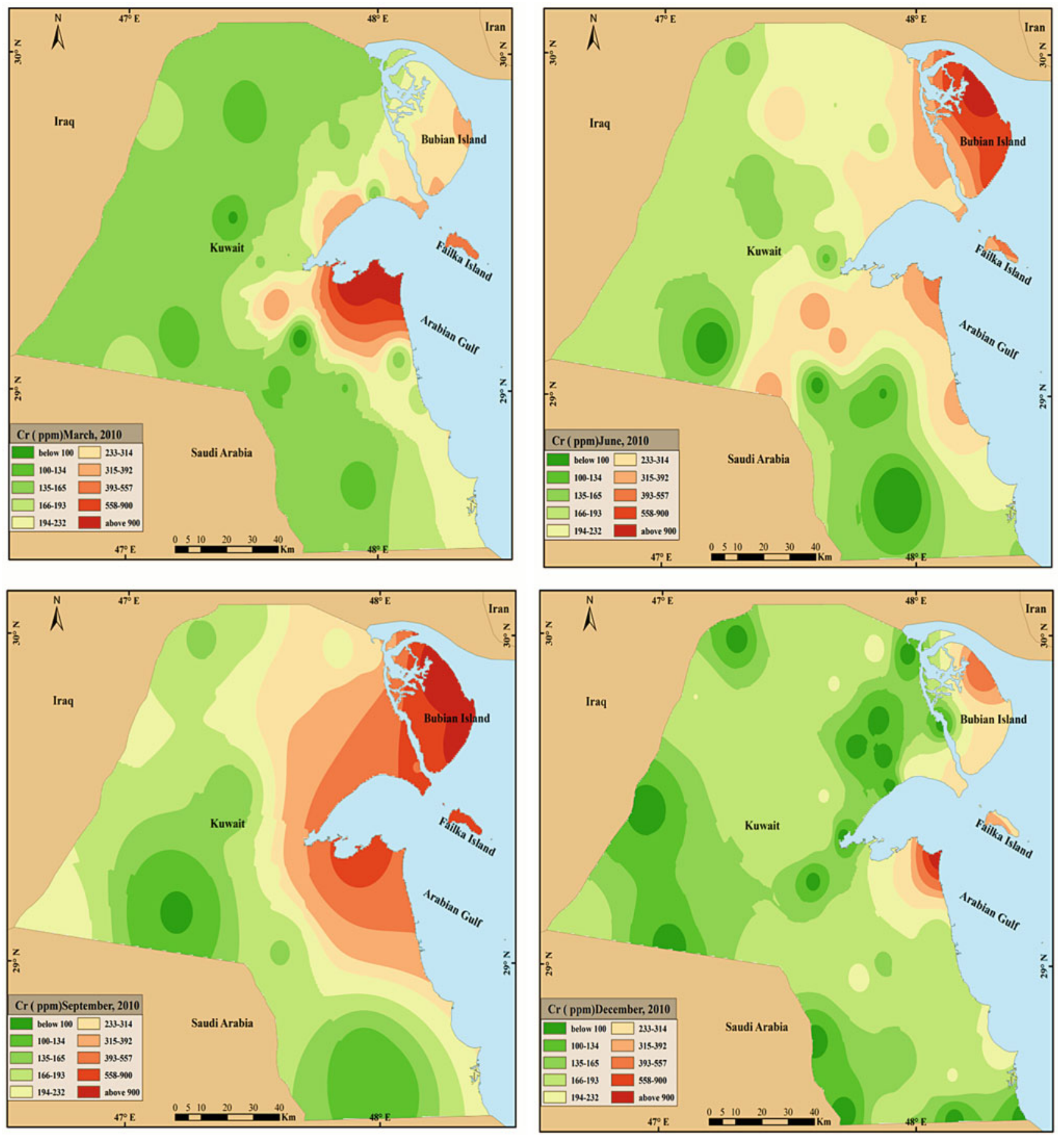

Fig. 5.10 $\mathrm{Cr}$ content in ppm within fallen dust in Kuwait (2010) 


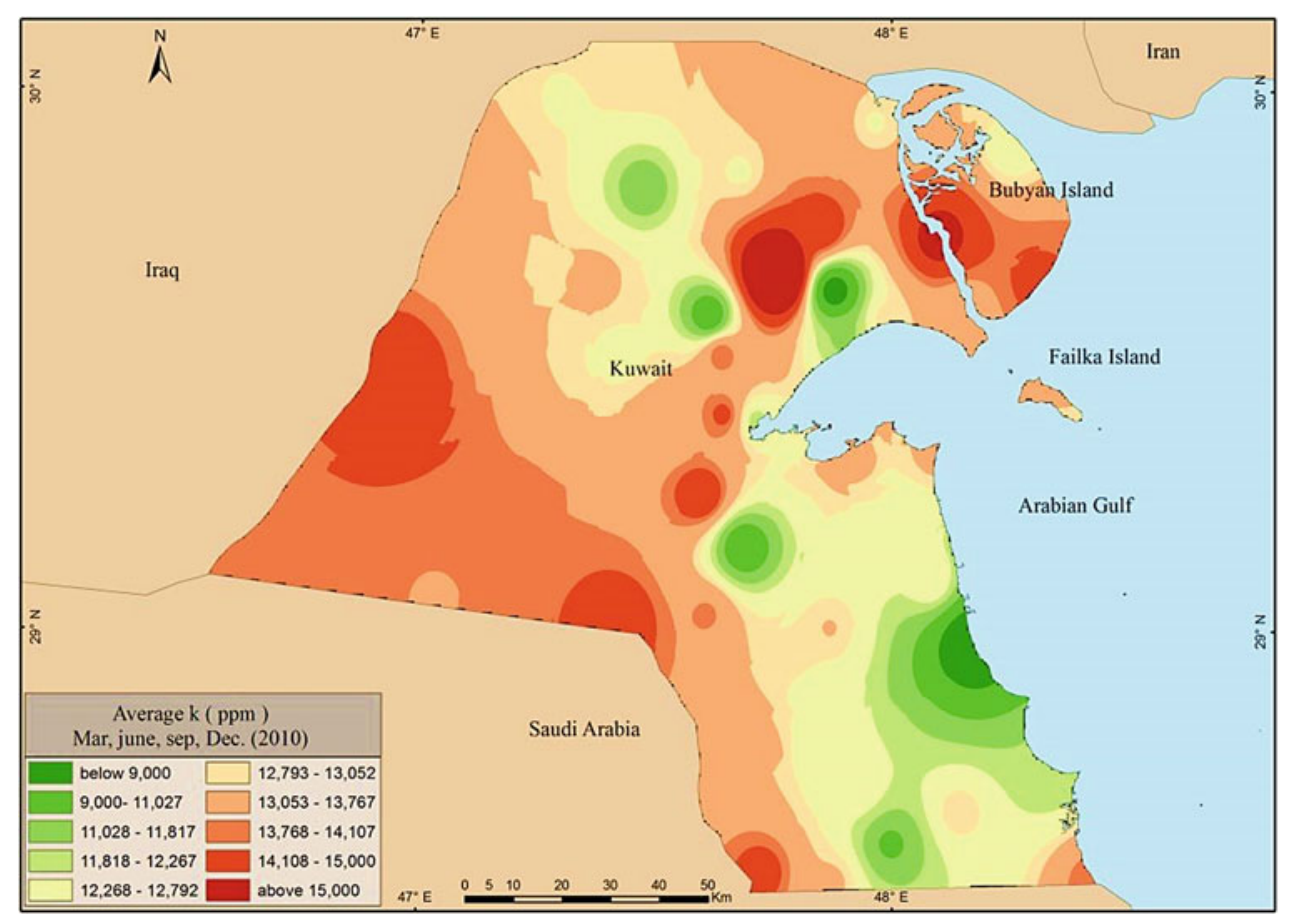

Fig. 5.11 Average potassium (K) content in ppm within fallen dust in Kuwait (2010)
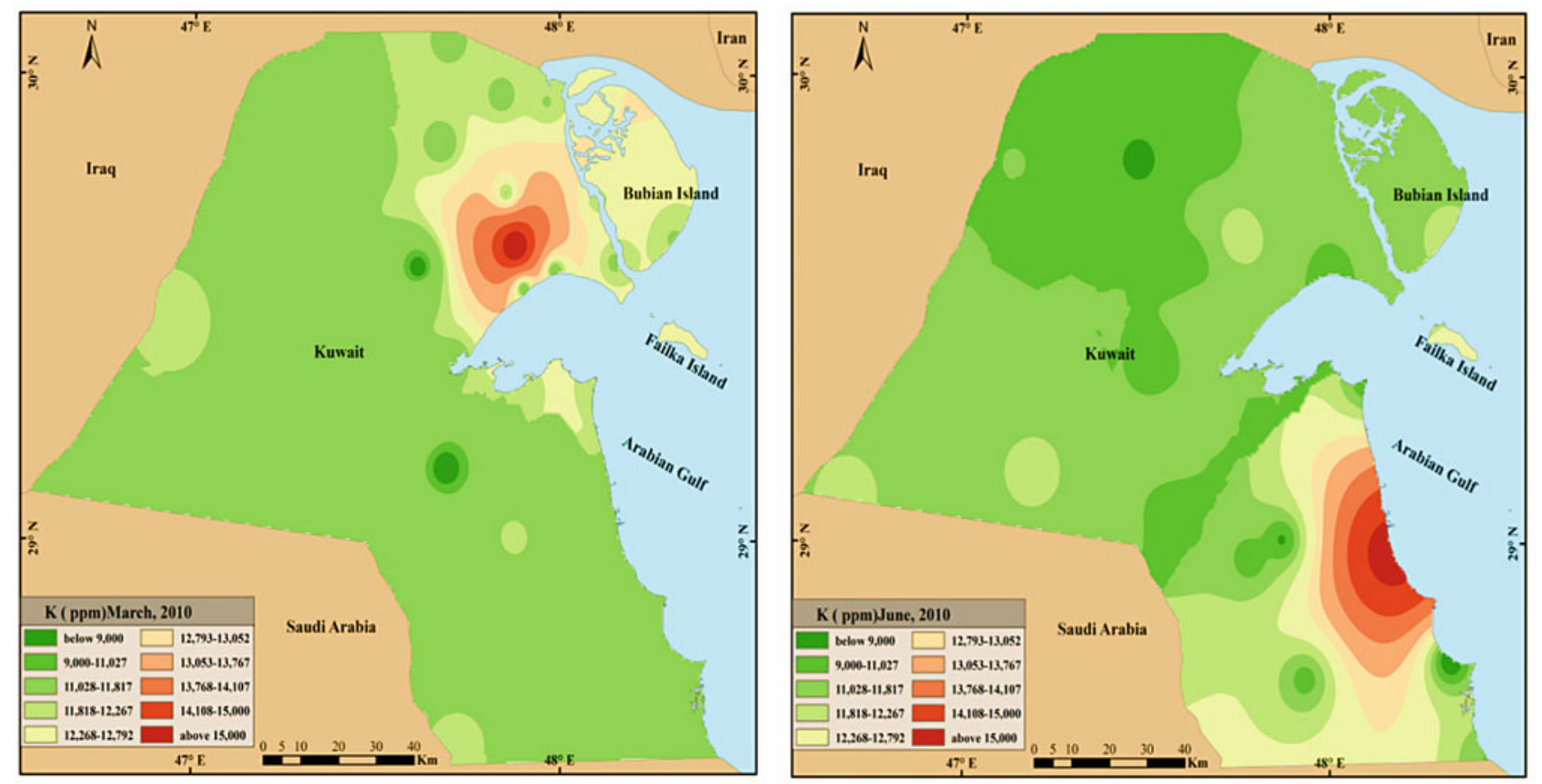

Fig. 5.12 K content in ppm within fallen dust in Kuwait (2010) 

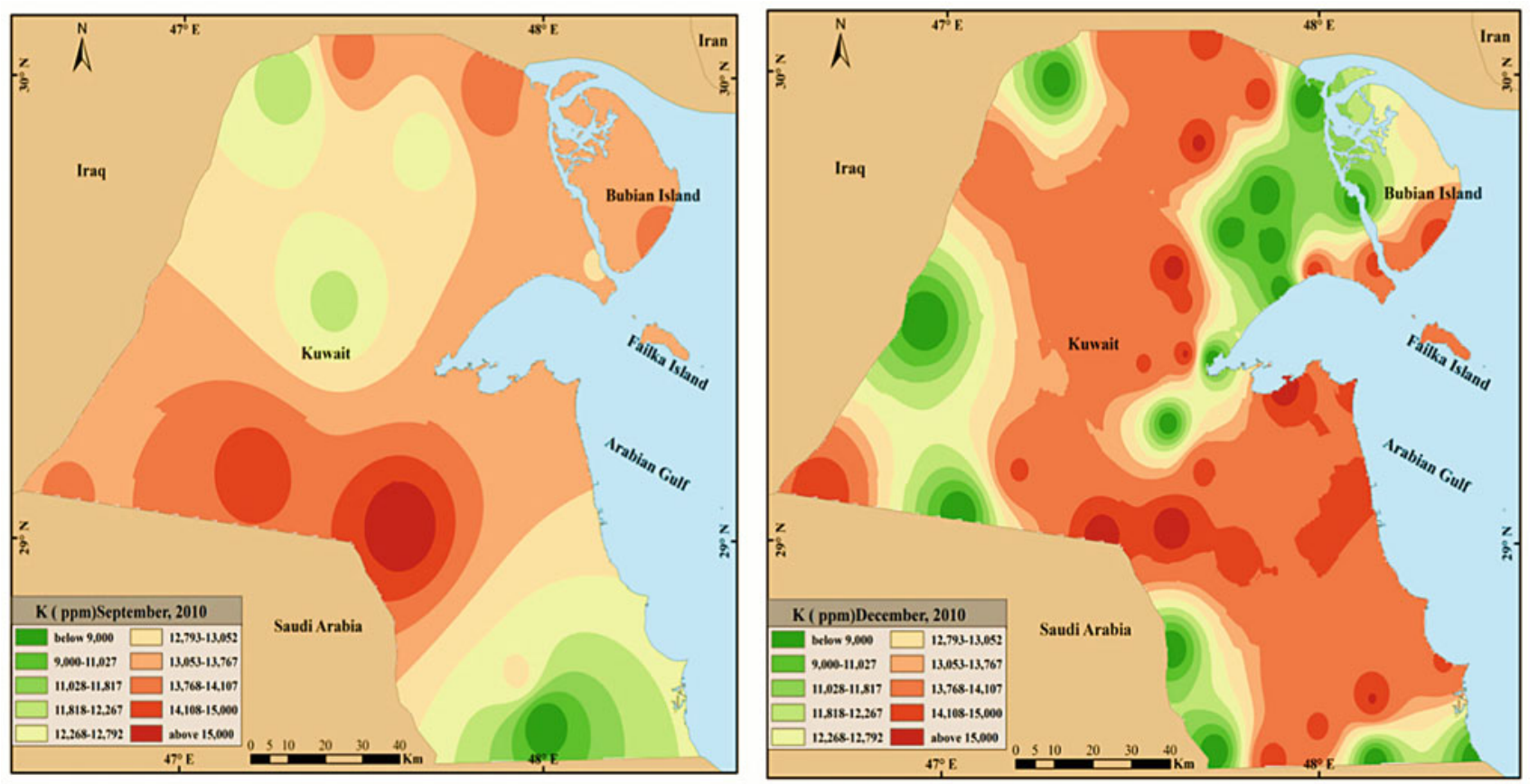

Fig. 5.12 (continued)

Fig. 5.13 Average magnesium $(\mathrm{Mg})$ content in ppm within fallen dust in Kuwait (2010)

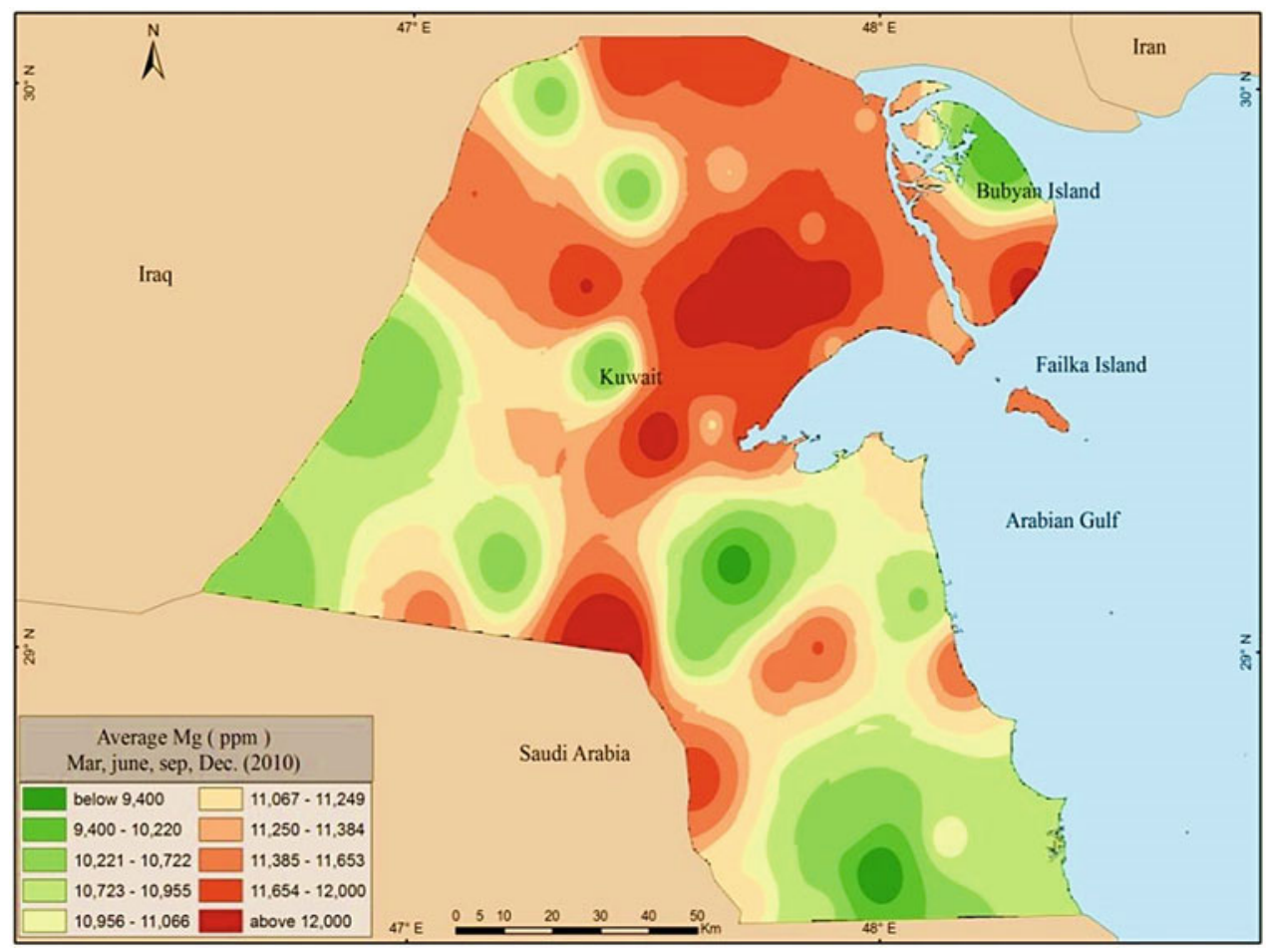



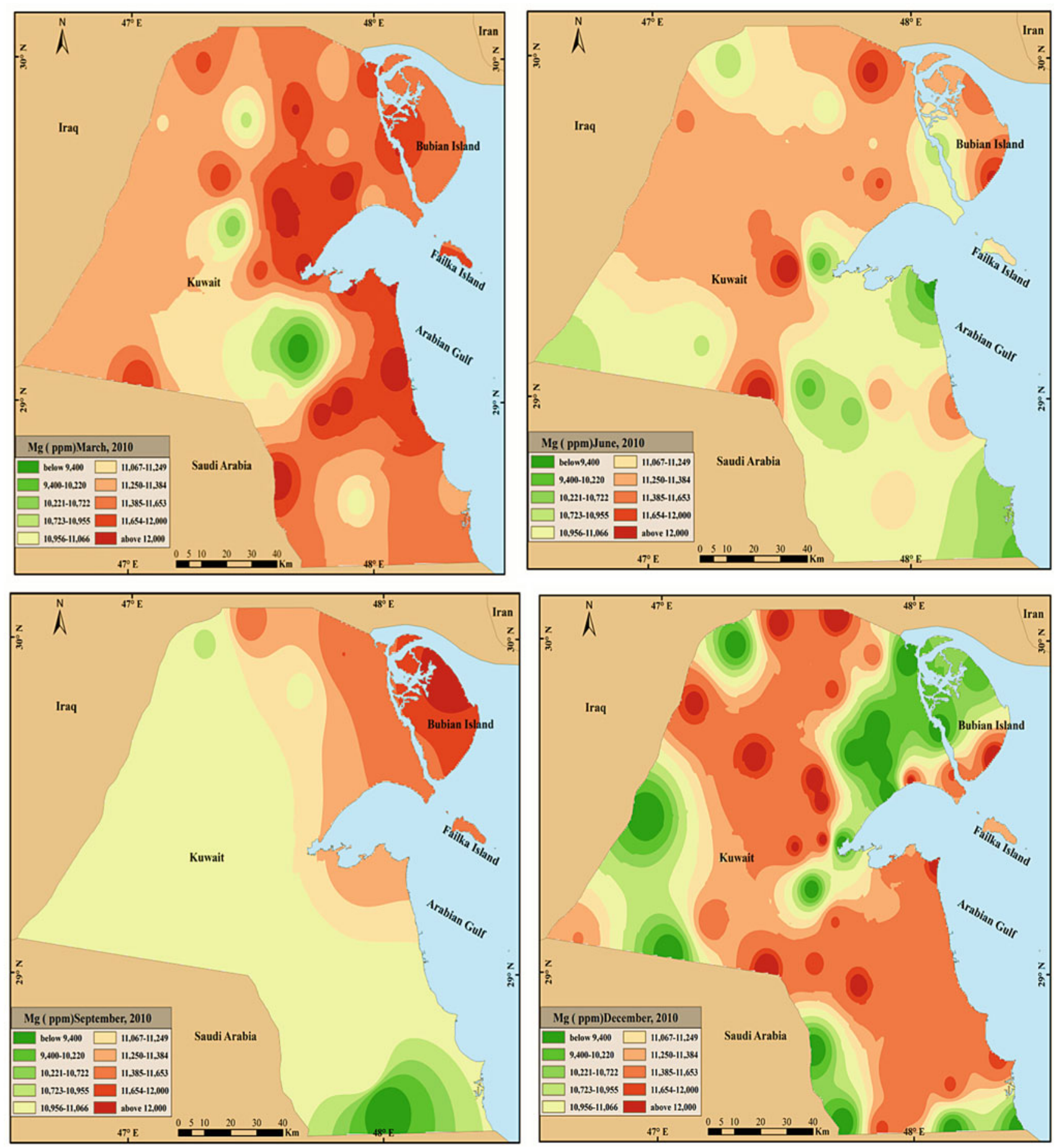

Fig. 5.14 Mg content in ppm within fallen dust in Kuwait (2010) 


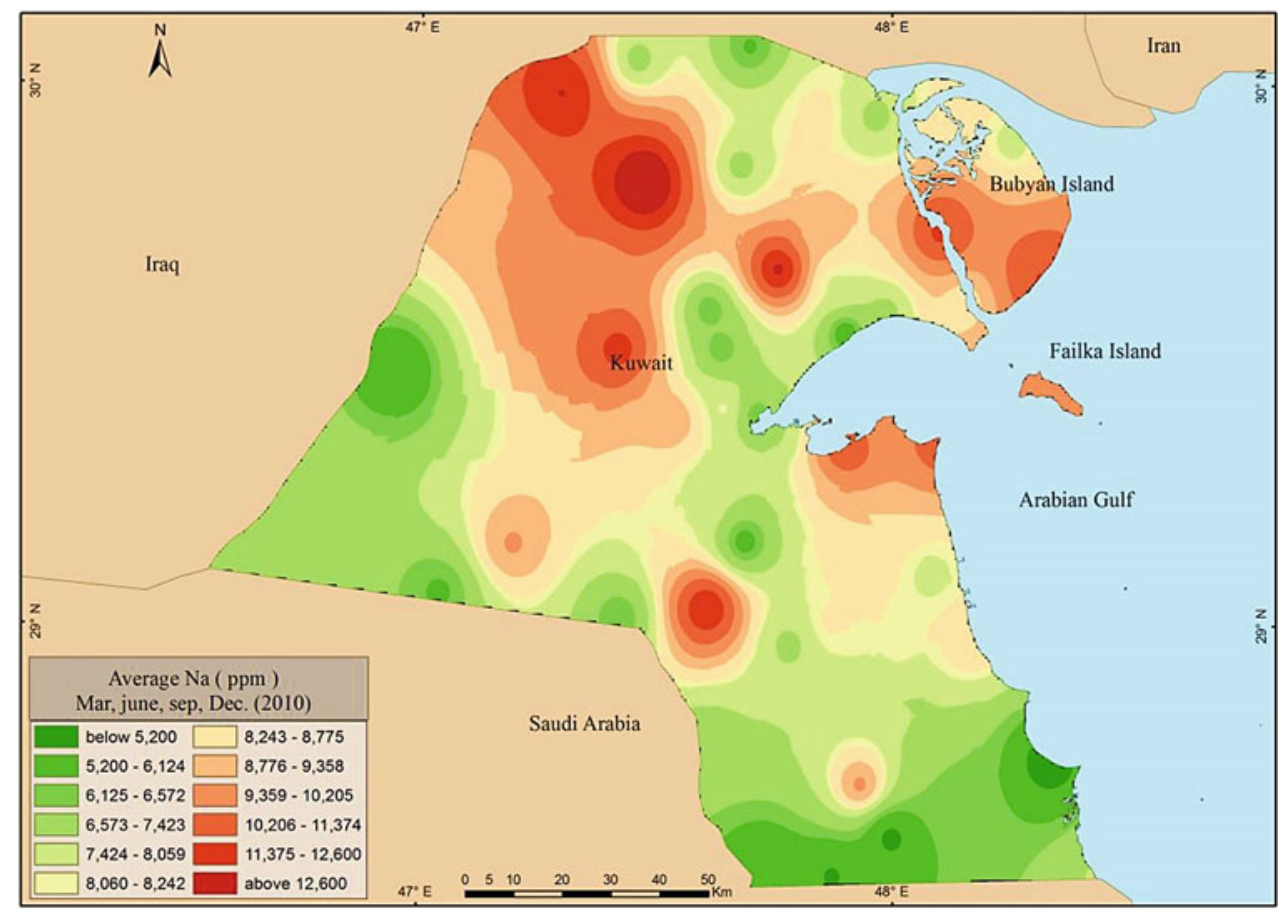

Fig. 5.15 Average sodium (Na) content in ppm within fallen dust in Kuwait (2010)
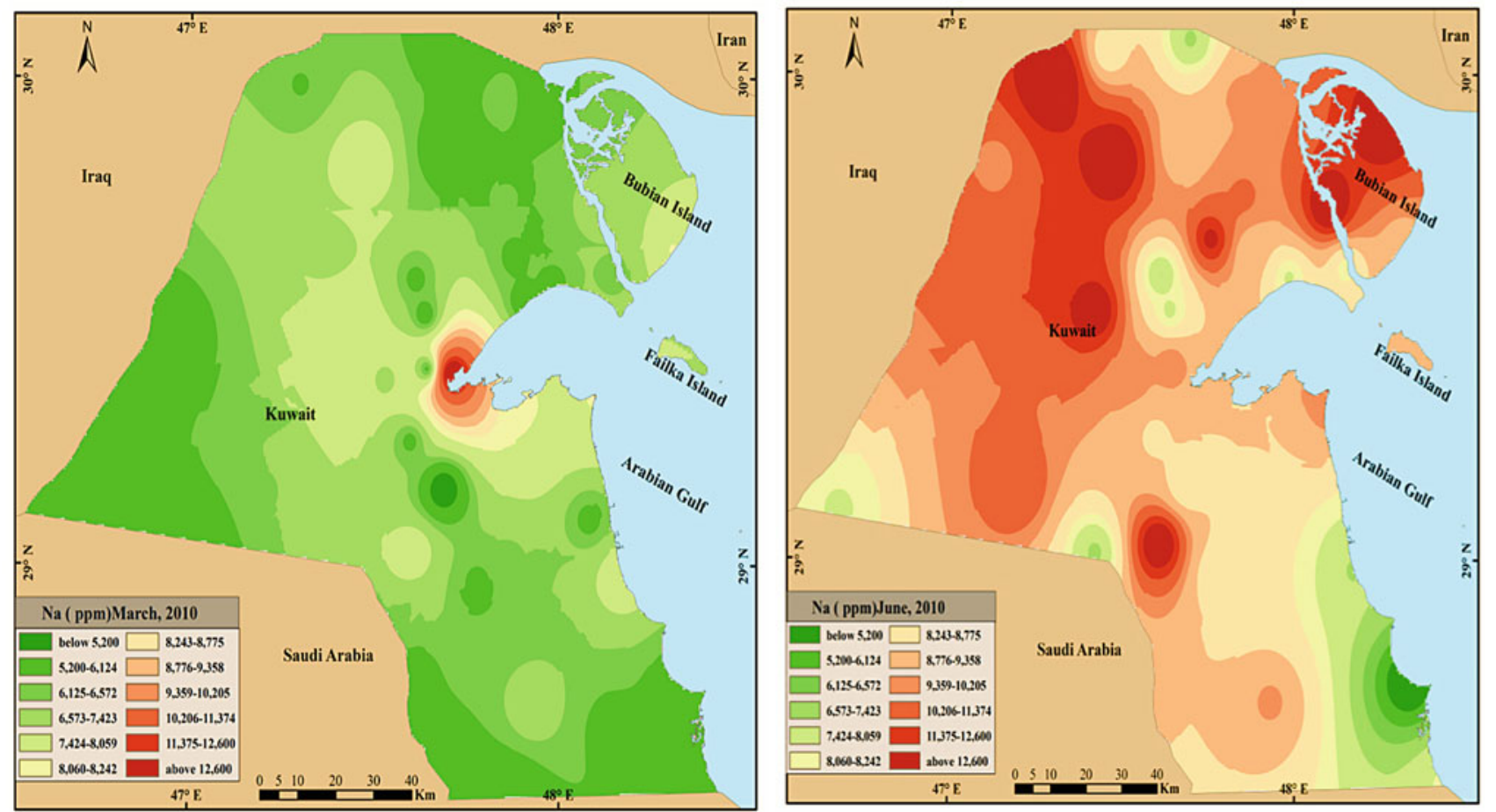

Fig. 5.16 Na content in ppm within fallen dust in Kuwait (2010) 

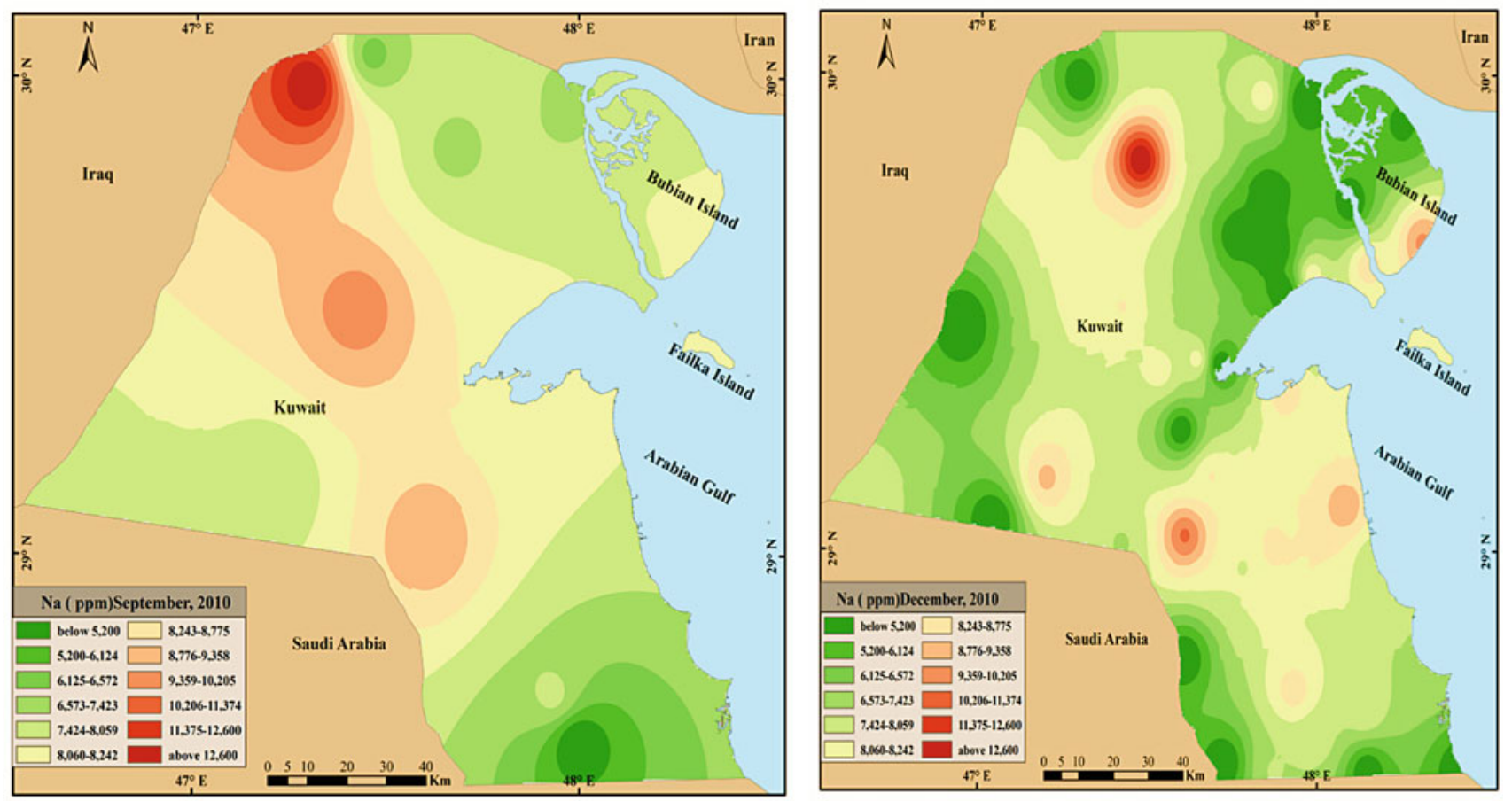

Fig. 5.16 (continued)

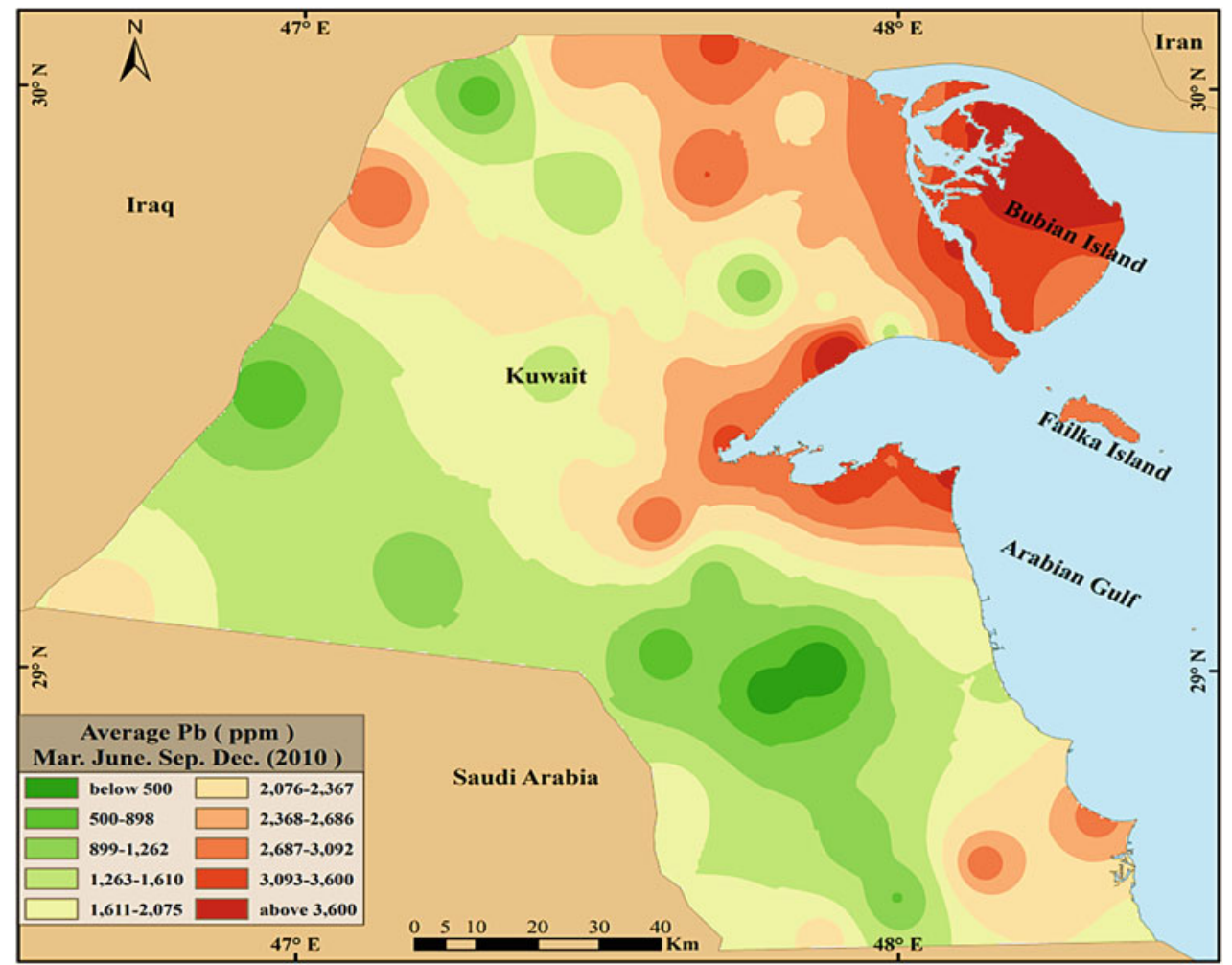

Fig. 5.17 Average lead $(\mathrm{Pb})$ content in ppm within fallen dust in Kuwait (2010) 

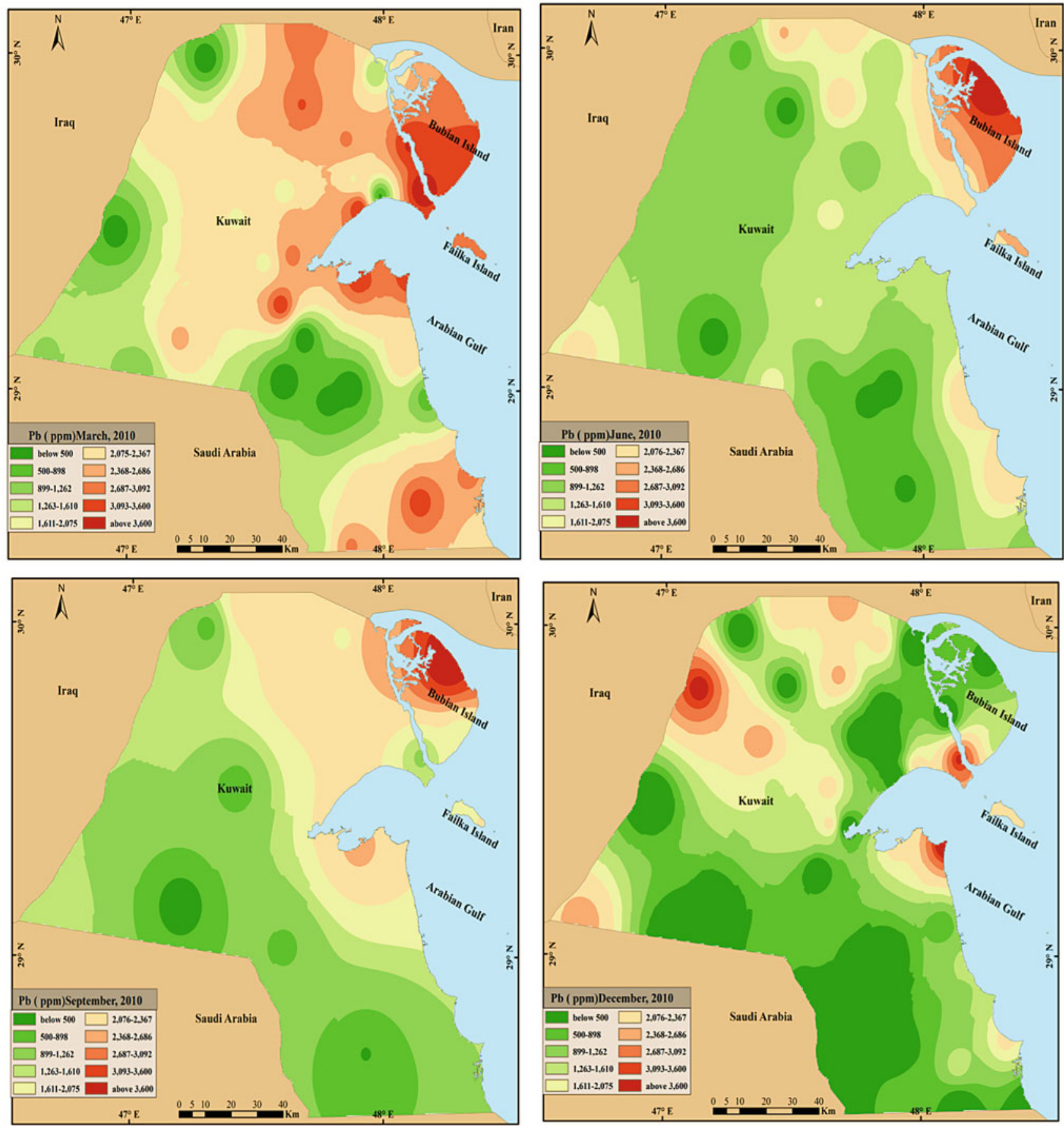

Fig. 5.18 $\mathrm{Pb}$ content in ppm within fallen dust in Kuwait (2010) 


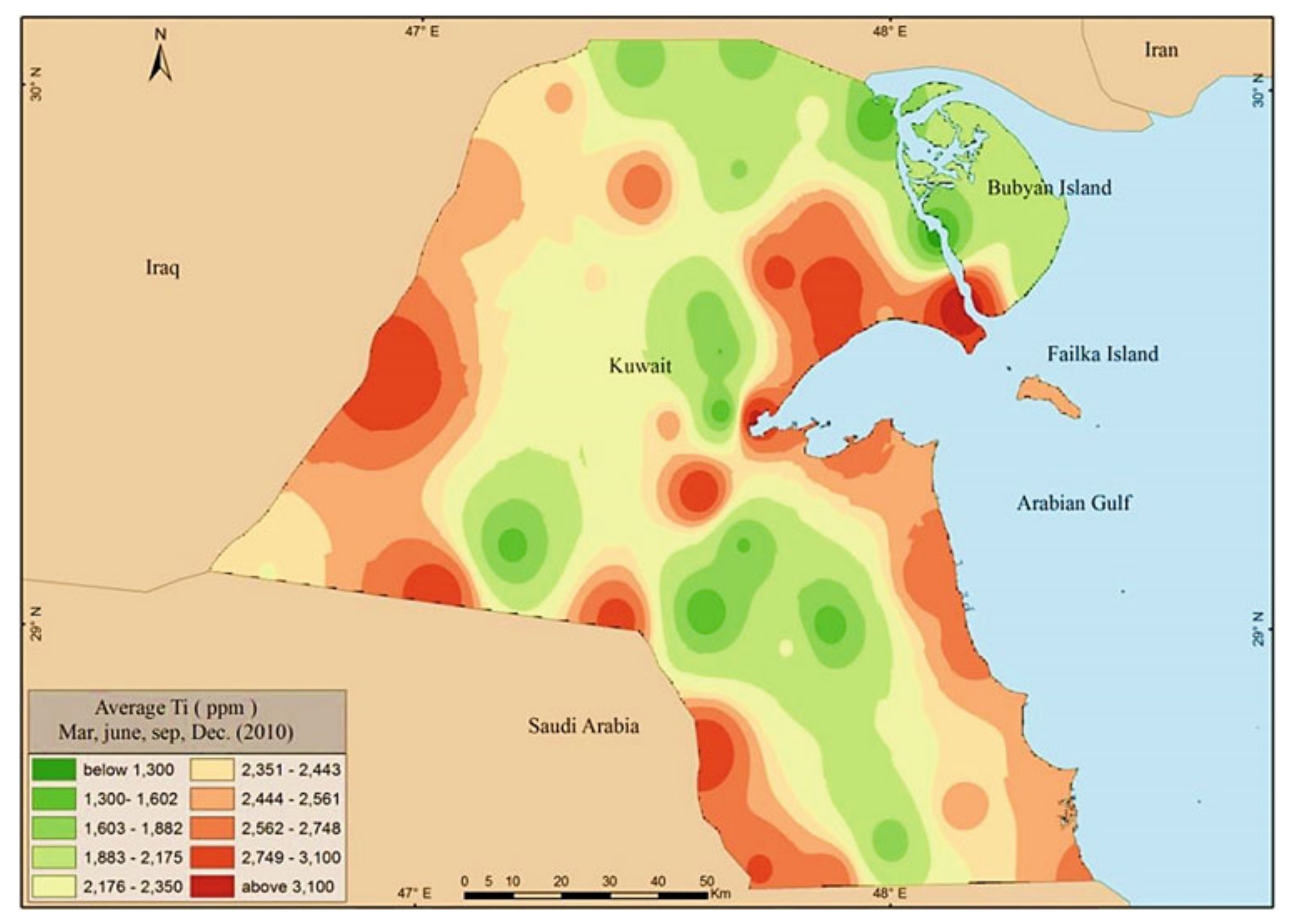

Fig. 5.19 Average titanium (Ti) content in ppm within fallen dust in Kuwait (2010)
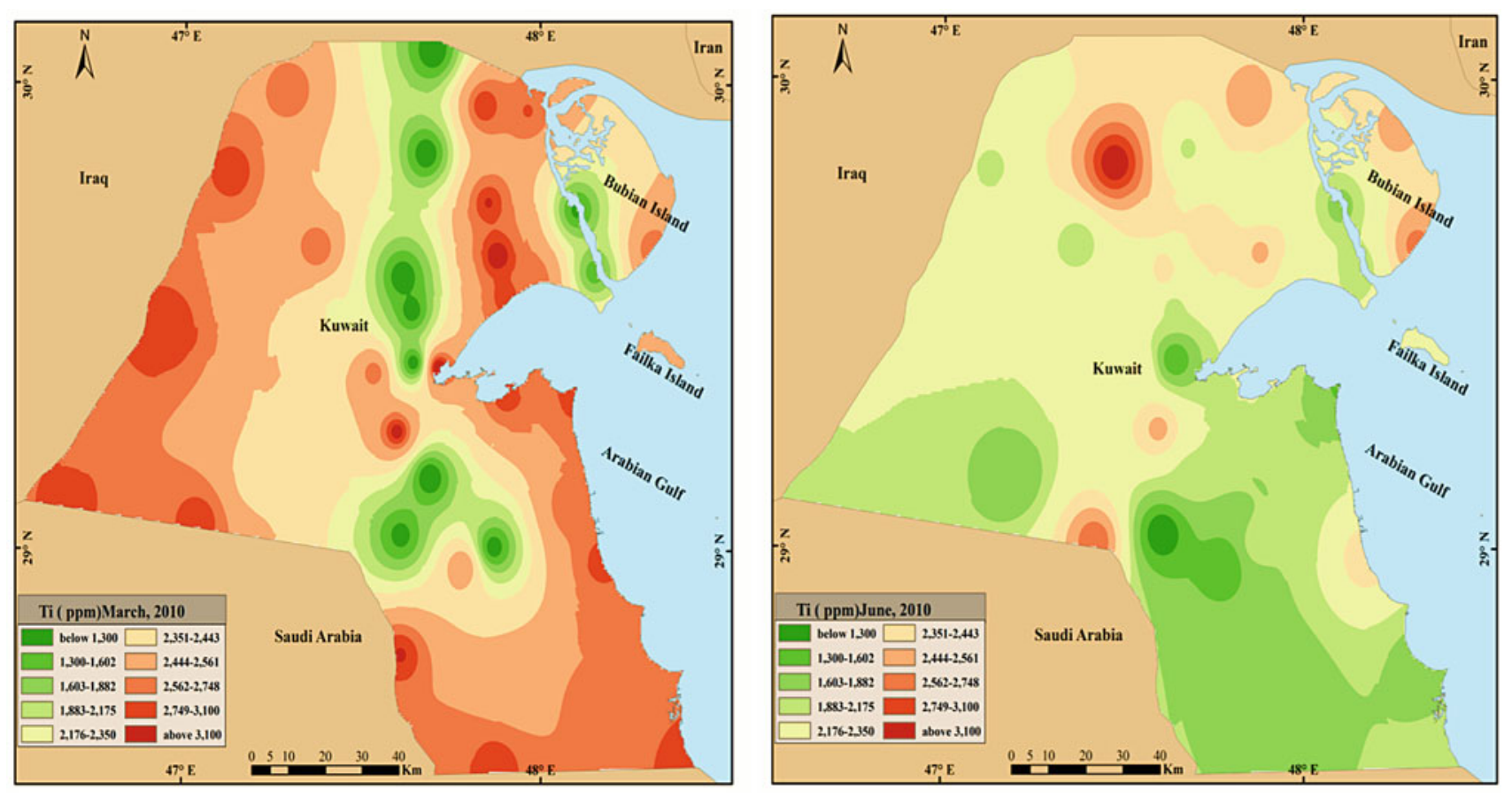

Fig. 5.20 Ti content in ppm within fallen dust in Kuwait (2010) 

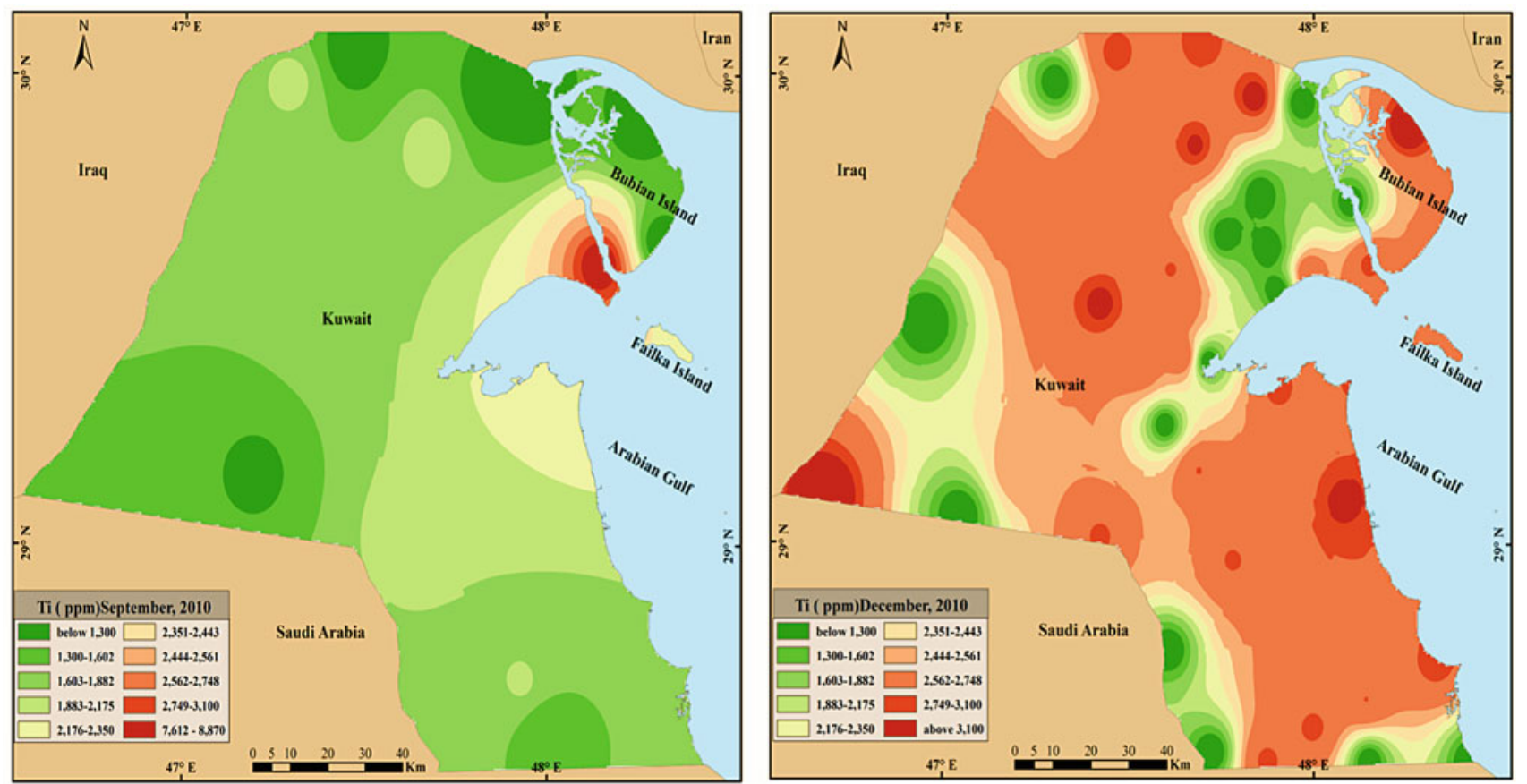

Fig. 5.20 (continued)

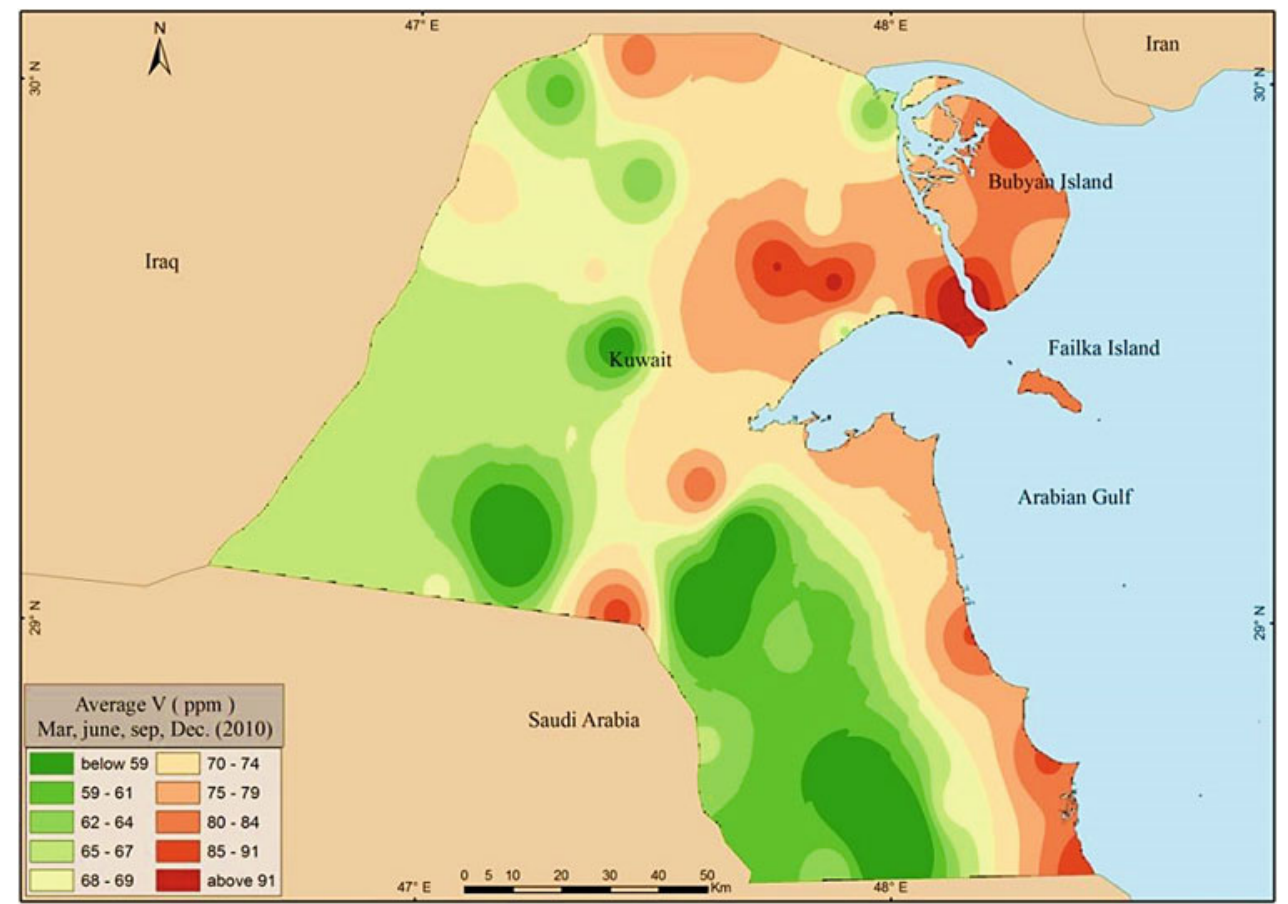

Fig. 5.21 Average vanadium (V) content in ppm within fallen dust in Kuwait (2010) 

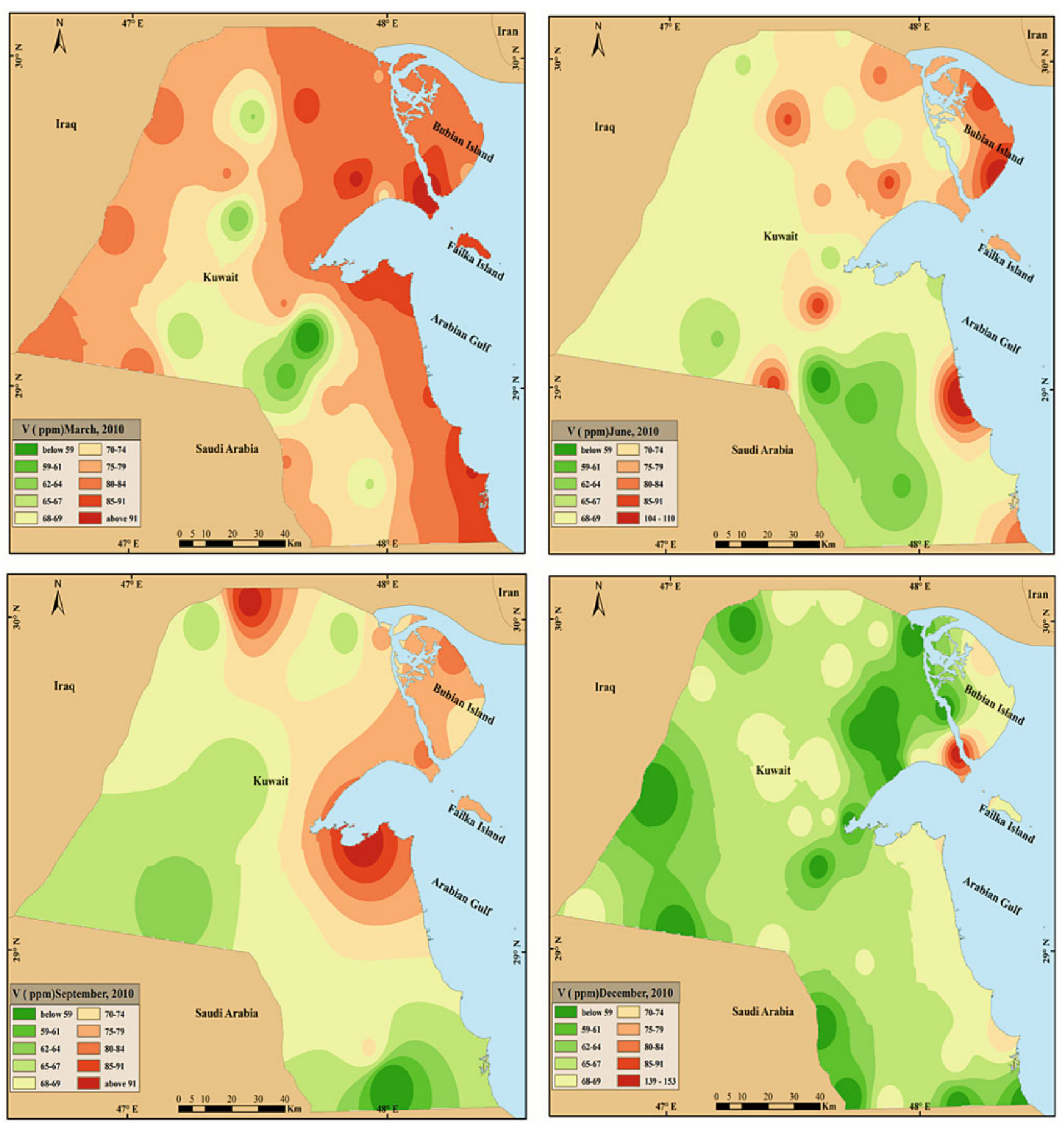

Fig. 5.22 V content in ppm within fallen dust in Kuwait (2010)

Open Access This chapter is licensed under the terms of the Creative Commons Attribution 4.0 International License (http:// creativecommons.org/licenses/by/4.0/), which permits use, sharing, adaptation, distribution and reproduction in any medium or format, as long as you give appropriate credit to the original author(s) and the source, provide a link to the Creative Commons licence and indicate if changes were made.
The images or other third party material in this chapter are included in the chapter's Creative Commons licence, unless indicated otherwise in a credit line to the material. If material is not included in the chapter's Creative Commons licence and your intended use is not permitted by statutory regulation or exceeds the permitted use, you will need to obtain permission directly from the copyright holder. 